\title{
Field monitoring evaluation of geotextile-reinforced soil-retaining walls
}

\author{
C. V. S. Benjamim ${ }^{1}$, B. S. Bueno ${ }^{2}$ and J. G. Zornberg ${ }^{3}$ \\ ${ }^{1}$ Ober S.A. Indústria e Comércio, Rua Herval, No. 348, CEP: 03062-000, São Paulo/SP, Brazil, \\ Telephone: +55 116090 3328, Telefax: +55 116693 4701,E-mail: vbenjamim@yahoo.com \\ ${ }^{2}$ Geotechnical Department, University of São Paulo, Av. Trabalhador Sancarlense, No. 400, CEP: \\ 13566-590, São Carlos/SP, Brazil, Telephone: +55 163373 9505, Telefax: +55 163373 9509, \\ E-mail: bsbueno@sc.usp.br \\ ${ }^{3}$ Civil Engineering Department, University of Texas at Austin, 1 University Station C1792, Austin, \\ TX 78712-0280, USA, Telephone: +1 512471 6548, Telefax: +1 5124716548 , \\ E-mail: zornberg@mail.utexas.edu
}

Received 13 February 2006, revised 11 December 2006, accepted 16 January 2007

\begin{abstract}
The use of geotextiles as reinforcement in soil-retaining walls may offer benefits over the use of other types of reinforcement, such as metallic strips or geogrids. These include ease of construction, expediency, and significant cost reduction. However, the lack of field monitoring results documenting the behavior of geotextile-reinforced structures, mainly regarding deformations, has precluded widespread utilization of these systems. A better understanding of the behavior of geotextile-reinforced soil structures could be gained by systematic monitoring of full-scale structures, combined with a thorough material characterization program. Accordingly, eight prototype geotextile-reinforced soil structures were built as part of a comprehensive study aimed at analyzing their behavior. This paper presents the characteristics of the prototype wall used as baseline for this series of structures, including construction details, instrumentation layout, and the results of laboratory tests conducted to characterize the soils and geosynthetics involved in this structure. The lateral displacements at the face of the wall were small, with increasing lateral displacements observed over time, particularly in association with precipitation events during the summer season in Brazil. The largest horizontal strains occurred towards the face, at mid-height of the prototype wall. The use of sigmoid curves to fit displacement results within the geotextiles was found to be very useful to define the value and the location of the peak strain in each reinforcement layer. The location of maximum reinforcement strains within each layer was found to be consistent with the development of a potential failure surface starting at the toe of the wall and propagating into the soil mass. The maximum reinforcement tension predicted using the K-stiffness method was found to compare well with reinforcement tension values obtained from monitoring results.
\end{abstract}

KEYWORDS: Geosynthetics, Reinforced soil walls. Geotextile, Cohesive soils, K-stiffness method

REFERENCE: Benjamim, C. V. S., Bueno, B. S. \& Zornberg, J, G. (2007). Field monitoring evaluation of geotextile-reinforced soil-retaining walls. Geosynthetics International, 14, No. 2, 100-118 [doi: 10.1680/gein.2007.14.2.100]

\section{INTRODUCTION}

Unlike in many countries, retaining walls in Brazil have often been reinforced using geotextiles instead of other reinforcement inclusions such as geogrids and metallic reinforcements. This approach is reported to have several advantages, such as ease of construction, expediency, and significant cost reduction. However, the current lack of data on the field performance of geotextile-reinforced structures in Brazil, mainly regarding their anticipated displacements, has precluded their utilization in critical structures.

In Brazil, as in many other countries, reinforced soil structures have replaced traditional retaining walls, such as concrete gravity and cantilevered walls. Soil reinforcement involves the use of tensile elements such as metallic strips, geosynthetics or wire meshes between compacted soil layers. Modern reinforced soil technology was developed in the early 1970s, when French architect Henry 
Vidal invented a technique he called Reinforced Earth. The original system uses metallic strips connected to concrete panels, which constitute the facing of the reinforced system (Vidal 1966).

Geosynthetics were first used as soil reinforcement inclusions in France in the early 1960s, when RhônePoulenc's engineers used geotextiles in geotechnical applications such as unpaved roads, railroads and earth dams. Subsequently, in countries such as the Netherlands and England, geosynthetics were used as reinforcement in retaining walls, providing an alternative to the original Reinforced Earth approach.

In Brazil, geosynthetics have been used since the early 1970s, mainly in drainage applications. The first significant reinforced soil slope involving the use of geotextiles as reinforcement elements (Carvalho et al. 1986) was constructed in 1984 to rebuild a failed embankment along Highway SP-123 in Campos do Jordão (São Paulo state).

The use of geosynthetics as reinforcement elements has become widely accepted worldwide. The polymeric industry has continually introduced new manufacturing techniques as well as stronger and stiffer products, which has made soil reinforcement using geosynthetics more attractive. The use of nonwoven geotextiles as reinforcement inclusions can provide additional advantages by allowing in-plane drainage and therefore allowing the use of finegrained soil as backfill material.

Most design guidelines for geosynthetic-reinforced structures recommend the use of granular soils as backfill material. This recommendation is prompted by concerns associated with poor drainage of fine-grained soils, which leads to both loss of soil shear strength and post-construction movements (Zornberg and Mitchell 1994). However, compacted fine-grained soils from tropical areas often show very good mechanical behavior, unlike fine-grained soils from temperate climates. For example, typical Brazilian soils from colluvium or residual origins show a high percentage of fines, but low plasticity, and an overall good mechanical behavior as compacted backfill (Cruz 1996).

The possibility of post-construction (creep) deformations, particularly when using polypropylene (PP) geotextiles, has been an additional concern that may have prevented the widespread use of geotextiles as reinforcement inclusions. The lack of creep data for PP geotextiles has often led to the use of creep reduction factors as high as 5. The use of such high creep reduction factors, and the comparatively lower tensile strength of nonwoven geotextiles, has relegated the use of nonwoven geotextiles to comparatively small structures subjected to conventional surcharges.

The difficulty in predicting the behavior of geotextilereinforced soil structures using current available design methods has been reported extensively in the technical literature. This was illustrated by Wu (1992), who requested predictions on the behavior of a highly instrumented reinforced soil structure. The predicted results showed a significant scatter when compared with the monitored response of the prototype wall. Many factors have contributed to such discrepancies, including the contribution of suction to the soil shear strength, the increased stiffness shown by reinforcements under the confinement of soil, and the contribution of soil arching to the stability of the structure. Field observation of the behavior of prototype walls still constitutes a clear need. However, the instrumentation of prototype walls is expensive, and the collected field data often address only limited aspects that govern the overall behavior of the structures.

Studies on the behavior of geotextile-reinforced structures have been conducted using small-scale physical modeling, such as centrifuge models (e.g. Zornberg and Arriaga 2003) and numerical modeling using the finite element method (e.g. Pedroso et al. 2006). Owing to the difficulties in reproducing construction procedures when using numerical and small-scale situations, instrumented large-scale laboratory tests have also provided valuable results (e.g. Bathurst et al. 1989). Although these studies have provided significant insight into the behavior of geotextile-reinforced soil structures, additional data from instrumented prototype walls would continue to provide invaluable information in understanding the effect of variables governing the wall response.

An important set of data on the behavior of prototype structures was reported by Christopher (1993), who evaluated 12 retaining wall and steep slope prototypes for structures with different facings (gabion, geosynthetic, concrete panels) and reinforcement types (geotextile, metallic strips). Farrag and Morvant (2004) also constructed full-scale reinforced test walls with low-quality backfill in order to investigate the interaction mechanisms between various geosynthetic materials and silty clay backfill. Finally, Allen et al. (2002) presented a summary of 20 well-documented geosynthetic wall case histories, covering a wide variety of wall heights, surcharge loadings, foundation conditions, facing and reinforcement types, and inclusion spacings.

In Brazil, experimental studies using geotextiles as soil reinforcement have been conducted by Ehrlich et al. (1997) and Ribeiro et al. (1999). However, no studies have been reported so far on large-scale prototype walls, particularly considering the use of typical Brazilian soils as backfill material.

With the objective of generating a database of instrumented structures, eight geotextile-reinforced soil-retaining prototype walls were constructed by the Geosynthetics Research Group at the University of São Paulo at São Carlos. These structures were instrumented to obtain the internal distribution of reinforcement strains as well as the overall vertical and horizontal movements. This paper presents the characteristics and behavior of one of the structures, Prototype Wall 1, which is considered a baseline case for future comparative evaluations. This paper summarizes the reinforcement layout, the laboratory program conducted to characterize the soil and reinforcements, the instrumentation monitoring program, and the construction methodology.

The instrumentation results include the vertical and horizontal movements of the wall, as well as the reinforcement internal displacements measured both during wall construction and up to 203 days after construction. Interpretation of the reinforcement displacements of prototype 
wall 1 allows determination of the reinforcement loads, which is used to assess the behavior of the wall using design methods that account for the structure deformations (e.g. the K-stiffness method).

\section{OVERVIEW OF THE FIELD MONITORING PROGRAM}

The instrumented wall prototype investigated in this study is the baseline structure of a series of eight prototype walls constructed by the Geosynthetics Research Group at the University of São Paulo at São Carlos. While the focus of this paper is on the behavior of the baseline wall (prototype wall 1), a brief description of the overall field monitoring program is provided in this section.

Figure 1 shows the general configuration of the prototype walls. In order to maximize the information collected in this field monitoring program, the prototype walls were built in pairs (twin walls constructed back to back). The eight geotextile-reinforced retaining walls were designed, built and instrumented in order to investigate the effect of soil type, geotextile type and reinforcement layout. Three prototype wall pairs were constructed using the same type

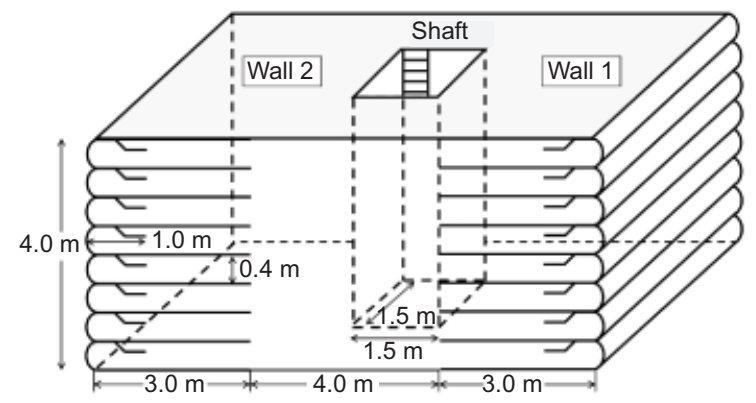

Figure 1. Configuration of prototype walls of soil, but using different reinforcement types. Two prototype walls were constructed using the same soil and geotextile type, but with different reinforcement layout. Finally, and in order to exacerbate post-construction movements, one of the prototype walls was designed using a reduction factor (combined reduction factor due to installation damage, creep and durability) of 1 . The characteristics of the eight prototype walls built as part of that study are summarized in Table 1.

The prototype walls were built using wrap-around facing, with a face overlap length of $1.0 \mathrm{~m}$. No seams were used during placement of the reinforcements. Placement of the reinforcement at the face involved the use of metallic supports and wood lagging boards (Figure 2), which allowed a face inclination of $78^{\circ}$ with the horizontal (batter of 1H:5V). Some of the walls involved the use of granular backfill, which was compacted using a vibratory

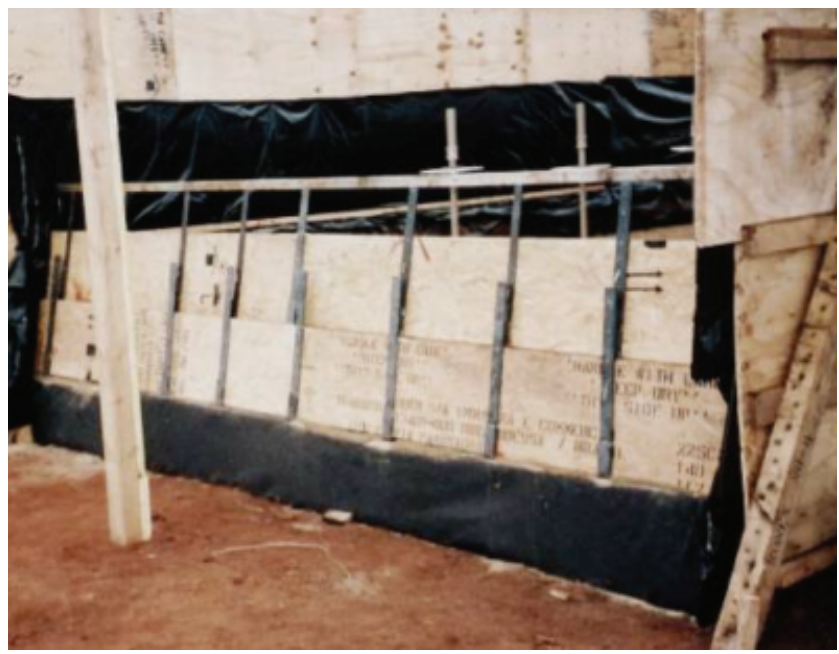

Figure 2. Photograph of wood lagging board supports used during construction

Table 1. Characteristics of prototype walls

\begin{tabular}{|c|c|c|c|c|c|}
\hline \multirow[t]{2}{*}{ Wall } & \multicolumn{3}{|c|}{ Geotextile } & \multirow[t]{2}{*}{ Reinforcement layout $^{\mathrm{a}}$} & \multirow[t]{2}{*}{ Soil type } \\
\hline & Product name & Type & Polymer & & \\
\hline 1 & Ober G200 & Nonwoven & PET & $\begin{array}{l}\text { Uniform spacing } \\
S_{\mathrm{v}}=0.40 \mathrm{~m}\end{array}$ & SP \\
\hline 2 & Ober G200 & Nonwoven & PET & $\begin{array}{l}\text { Non-uniform spacing } \\
S_{\mathrm{v}}=0.30 \mathrm{~m} \text { to } 0.50 \mathrm{~m}\end{array}$ & SP \\
\hline 3 & Ober G250 & Nonwoven & PP & $\begin{array}{l}\text { Non-uniform spacing } \\
S_{\mathrm{v}}=0.30 \mathrm{~m} \text { to } 0.50 \mathrm{~m}\end{array}$ & SM \\
\hline 4 & Propex $10 \times 50$ & Woven & PP & $\begin{array}{l}\text { Non-uniform spacing } \\
S_{\mathrm{v}}=0.30 \mathrm{~m} \text { to } 0.50 \mathrm{~m}\end{array}$ & SM \\
\hline 5 & Ober G250 & Nonwoven & PP & $\begin{array}{l}\text { Uniform spacing } \\
S_{\mathrm{v}}=0.40 \mathrm{~m}\end{array}$ & CL \\
\hline 6 & Propex $10 \times 50$ & Woven & PP & $\begin{array}{l}\text { Uniform spacing } \\
S_{\mathrm{v}}=0.40 \mathrm{~m}\end{array}$ & CL \\
\hline 7 & Ober G150 & Nonwoven & PP & $\begin{array}{l}\text { Uniform spacing } \\
S_{\mathrm{v}}=0.36 \mathrm{~m}\end{array}$ & SP \\
\hline 8 & Propex 10x50 & Woven & PP & $\begin{array}{l}\text { Uniform spacing } \\
S_{\mathrm{v}}=0.40 \mathrm{~m}\end{array}$ & SP \\
\hline
\end{tabular}

${ }^{\text {a }}$ Reinforcement length is $3 \mathrm{~m}$ for all prototype walls. 


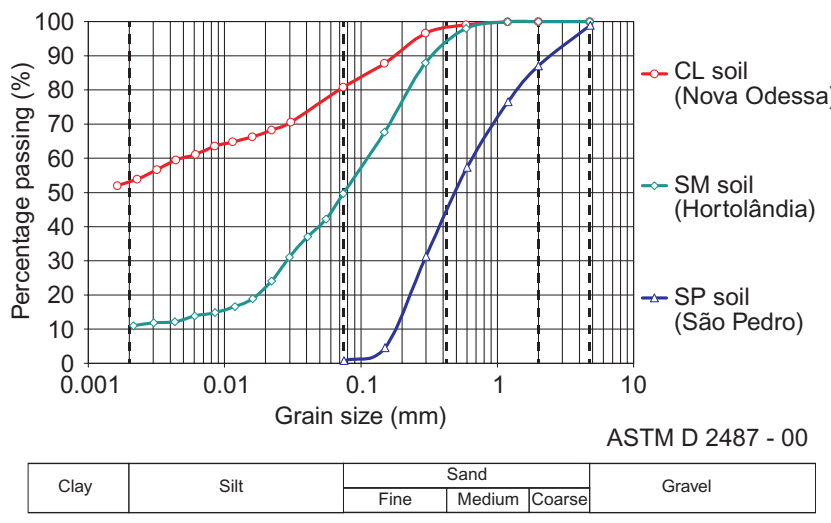

Figure 3. Particle size distributions for soils used in prototype walls.

plate, while the other walls used fine-grained backfill, which was compacted using a mechanical tamper.

Three different soils from tropical origin, two finegrained and one granular soil, were used as backfill material. The soils were tested to obtain the data needed for the design of the prototype walls and the analyses of their behavior. Figure 3 shows the particle size distribution of the soils used in the prototype walls. According to the Unified Soil Classification System (ASTM D 2487), the soils classify as a low-plasticity clay (CL), a sandy silt (SM), and a poorly graded sand (SP). According to the MCT (Miniature, Compacted, Tropical) classification for fine-grained soils (Nogami and Villibor 1981), the CL soil is a lateritic clayey sand, and the SM is a non-lateritic sandy soil.

The walls were confined laterally using longitudinal wood side walls. The walls were $4.0 \mathrm{~m}$ wide and $4.0 \mathrm{~m}$ high. The paired reinforced walls had a total length of $10.0 \mathrm{~m}$, so the total length of each wall (including a nonreinforced zone) is $5.0 \mathrm{~m}$. Geomembranes lined with grease were used along the wood side walls in order to minimize lateral friction between the soil and the wood and promote plane-strain test conditions. Direct shear tests were conducted to quantify the interface shear strength between the soil and the greased geomembranes. Table 2 summarizes the side wall/soil interface friction angles measured for the soils used in this study. The test results indicated that the interface shear strength is very small, with a friction angle of approximately $5.0^{\circ}$ for the finegrained soils and $7.6^{\circ}$ for the medium to fine sand. The measured interface friction angles are smaller than those reported by Arthur and Roscoe (1965) for dry sand in contact with glass $\left(\delta=14^{\circ}\right)$. Their study showed that side

Table 2. Shear strength of interface between soil and greased membranes located against test facility woodside walls

\begin{tabular}{|l|c|}
\hline Type of soil & Interface friction angle (degrees) \\
\hline Nova Odessa soil (CL) & 5.2 \\
Hortolândia soil (SM) & 4.9 \\
São Pedro soil (SP) & 7.6 \\
\hline
\end{tabular}

friction on small-scale walls did not significantly affect the behavior of their models. Similar conclusions were obtained by Zornberg and Arriaga (2003), who tested small-scale reinforced soil structures to failure in a geotechnical centrifuge. The centrifuge models were lined using Mylar sheets, which proved successful in minimizing side friction, as observed from careful post-failure assessment of the models.

Additional evidence that the walls behaved approximately in plane-strain conditions was provided by the slope of the surface crack that developed in the underdesigned wall constructed as part of this study. As shown in Figure 4, a wide transverse crack developed parallel to the prototype wall face (i.e. transverse to the wood side walls). While a curved crack pattern would have provided evidence of side friction, the shape of the crack indicates that the assumption of plane-strain conditions is reasonable.

Both woven and nonwoven geotextiles were used as reinforcement inclusions in the prototype walls. Also, both polypropylene (PP) and polyester (PET) products were used. This allowed comparison of wall performance for various geotextile and polymer types. Accordingly, the study allowed investigation of the effect of the ultimate tensile strength, stiffness, and creep properties on the behavior of geotextile-reinforced walls. While comparison of the behavior of the eight walls is beyond the scope of this paper, the behavior of the baseline wall is evaluated. Specifically, this paper provides the analysis of prototype wall 1, which used SP backfill and was reinforced with PET nonwoven geotextiles.

\section{DESCRIPTION OF THE BASELINE PROTOTYPE WALL}

\subsection{Wall characteristics}

Figure 5 shows a front view of prototype wall 1, which was constructed in July 2002, using a nonwoven geotextile as reinforcement and a medium to fine sand as backfill soil. The prototype wall was built using 10 geotextile layers placed with a vertical spacing of $0.40 \mathrm{~m}$.

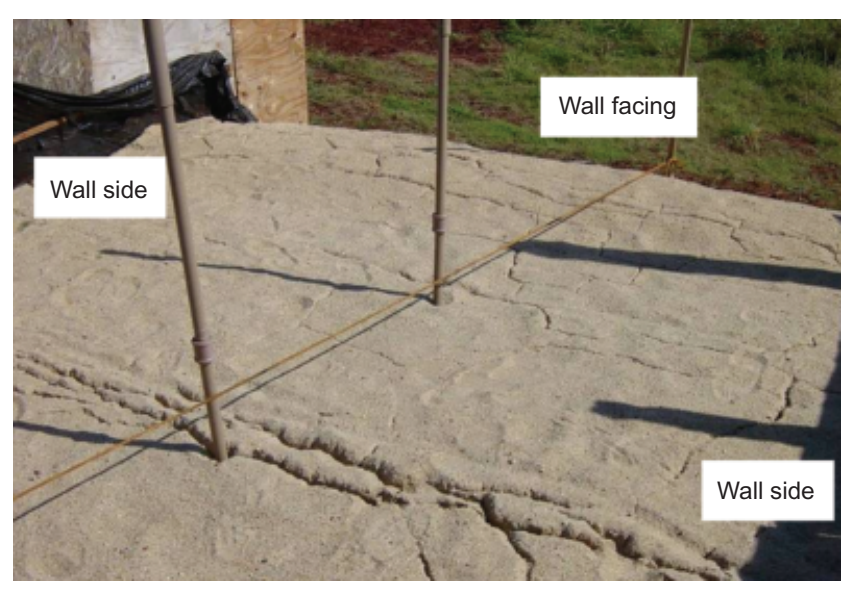

Figure 4. Photograph of transverse crack developed in prototype wall 7 


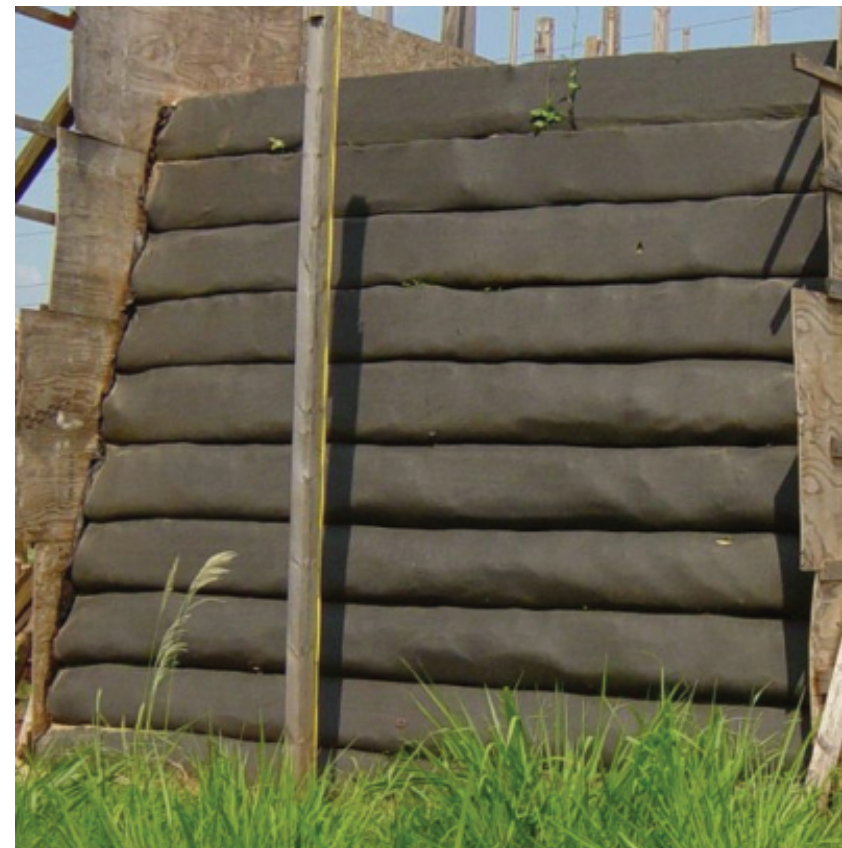

Figure 5. Front view of prototype wall 1

\subsection{Geotextile properties}

A short-fiber needle-punched polyester nonwoven geotextile was used as reinforcement in prototype wall 1. The geotextile is characterized as follows:

- $\quad$ mass per unit area: $204.4 \mathrm{~g} / \mathrm{m}^{2}$

- thickness: $1.26 \mathrm{~mm}$

- ultimate tensile strength: $8.41 \mathrm{kN} / \mathrm{m}$

- ultimate elongation: $89.8 \%$

- $\quad$ offset tensile modulus (ASTM D 4595): $13.0 \mathrm{kN} / \mathrm{m}$.

Creep tests (ISO 13341) were conducted using this geotextile in order to evaluate the post-construction movements observed in the prototype wall. The load levels used

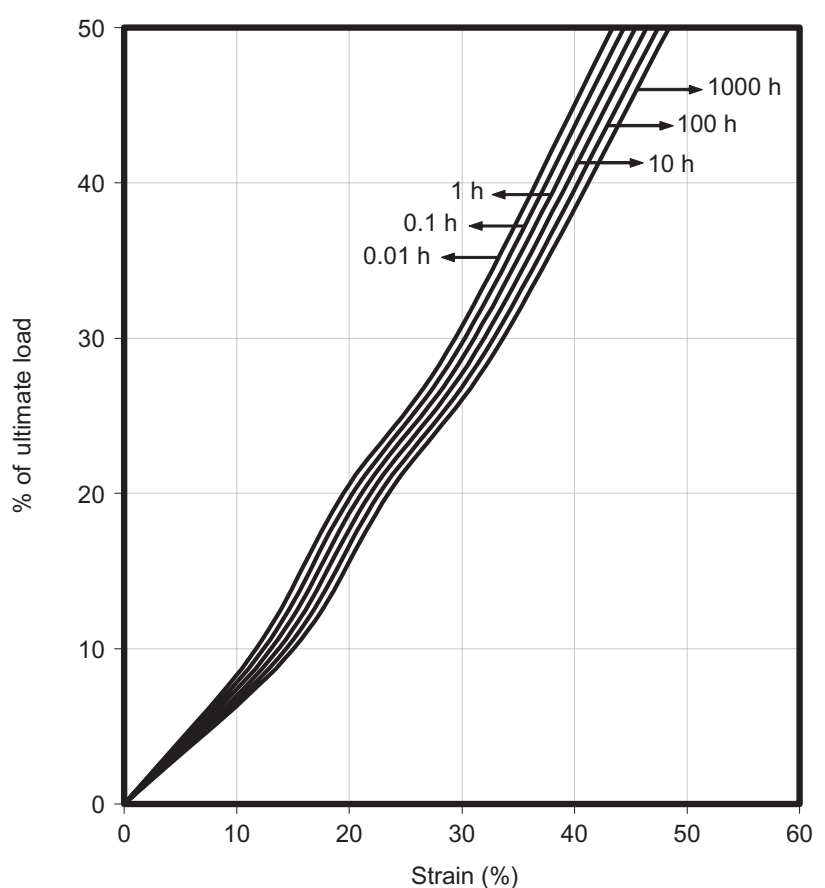

Figure 6. Geotextile isochronous curves

in the creep testing program were $10 \%, 20 \%, 30$ and $50 \%$ of the ultimate geotextile tensile strength. The measurements were registered using digital photography techniques (Baras et al. 2002). Figure 6 shows the isochronous curves obtained from the creep tests for the nonwoven PET geotextile used in this wall.

Tensile tests (ASTM D 4595) were conducted using three types of geotextile specimen: virgin samples, specimens retrieved after field placement (to characterize construction damage), and specimens subjected to UV exposure (approximately 200 days). Table 3 shows the results, which indicate that the retrieved specimens gave a slight increase $(6.5 \%)$ in tensile strength in the machine direction (MD) and a slight decrease $(2.1 \%)$ in the cross-

Table 3. Tensile test results of nonwoven geotextiles used in prototype wall 1

\begin{tabular}{|c|c|c|c|c|}
\hline \multicolumn{5}{|l|}{ Machine direction } \\
\hline \multirow[t]{2}{*}{ Sample type } & \multirow[t]{2}{*}{$\begin{array}{l}\text { Tensile strength } \\
(\mathrm{kN} / \mathrm{m})\end{array}$} & \multirow[t]{2}{*}{ Strain at failure $(\%)$} & \multicolumn{2}{|c|}{$\begin{array}{c}\text { Coefficient of variation } \\
\text { COV }(\%)\end{array}$} \\
\hline & & & Strength & Strain \\
\hline Virgin sample & 4.62 & 94.71 & 14.34 & 9.83 \\
\hline Retrieved from backfill & 4.92 & 56.16 & 12.70 & 10.67 \\
\hline UV exposure & 2.59 & 33.78 & 12.29 & 14.05 \\
\hline \multicolumn{5}{|l|}{ Cross machine direction } \\
\hline \multirow[t]{2}{*}{ Sample type } & \multirow[t]{2}{*}{$\begin{array}{l}\text { Tensile strength } \\
(\mathrm{kN} / \mathrm{m})\end{array}$} & \multirow[t]{2}{*}{ Strain at failure $(\%)$} & \multicolumn{2}{|c|}{$\begin{array}{c}\text { Coefficient of variation } \\
\text { COV }(\%)\end{array}$} \\
\hline & & & Strength & Strain \\
\hline Virgin sample & 8.12 & 95.85 & 10.42 & 3.57 \\
\hline Retrieved from backfill & 7.95 & 54.74 & 8.26 & 15.64 \\
\hline UV exposure & 5.10 & 31.68 & 20.89 & 10.34 \\
\hline
\end{tabular}


machine direction (CMD), compared with the virgin sample. The results also indicate that the retrieved specimens show a decreased strain at failure of $40.7 \%$ (MD) and $66.9 \%$ (CMD), which corresponds to increased reinforcement stiffness of $79.6 \%$ and $90.0 \%$, respectively. The exposed specimens showed a significant decrease in tensile strength (43.9\% for MD and $37.2 \%$ for CMD), although stiffness of the geotextiles increased after being exposed 200 days to UV (57.2\% for MD and $90.0 \%$ for CMD), compared with the virgin sample.

\subsection{Backfill properties}

The backfill material used in prototype wall 1 was the SP soil collected from the São Pedro region (Figure 3). The maximum and minimum void ratios, $e_{\max }$ and $e_{\min }$, according to ASTM D 4253 and ASTM D 4254, were 0.70 and 0.46 . The backfill soil was compacted to a target relative density of $80 \%$, which corresponds to a void ratio of 0.51 and a dry unit weight of $1.77 \mathrm{kN} / \mathrm{m}^{3}$. The backfill was placed in the field at a moisture content of approximately $5.0 \%$.

The shear strength of the soil was obtained from consolidated-drained (CD) triaxial tests on specimens prepared at the unit weight and water content used during construction of the prototype wall. The shear strength is characterized by a cohesive intercept of $16 \mathrm{kPa}$ and a friction angle of $33^{\circ}$.

The foundation soil where the prototype wall was constructed was characterized by in situ SPT (standard penetration test) results. Figure 7 shows the SPT profile, which indicates a profile with low blow counts. To minimize settlement and external stability problems the

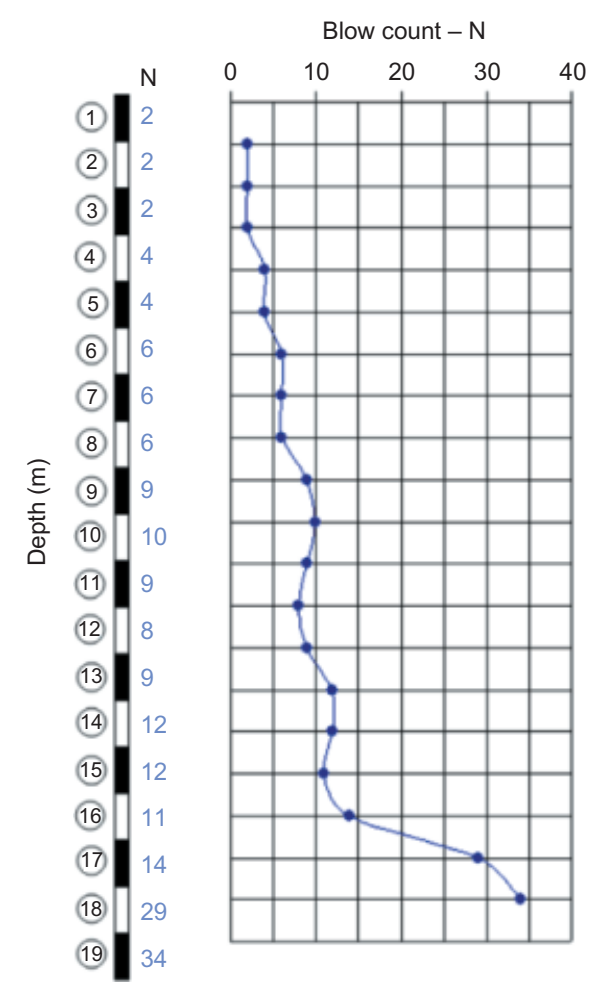

Figure 7. Results of standard penetration test in foundation soil prototype wall was constructed over a $0.40 \mathrm{~m}$ base layer of dense sand, which was reinforced using additional nonwoven geotextiles.

\subsection{Design overview}

Prototype wall 1 was designed using a conventional approach, consistent with that described by Mitchell and Villet (1987) and Elias et al. (2001). However, based on the test results obtained as part of this study, the reduction factors against creep, durability and installation damage were taken as 1 . Also, based on the results of the material program, a soil friction angle of $33^{\circ}$ was adopted while the cohesive intercept was neglected. The design assumptions of prototype wall 1 resulted in uniform reinforcement spacing, $S_{\mathrm{v}}$, of $0.4 \mathrm{~m}$ and a reinforcement length equal to $3.0 \mathrm{~m}$. The adopted facing inclination is $78^{\circ}$, which corresponds to a face slope of $1 \mathrm{H}: 5 \mathrm{~V}$.

\subsection{Instrumentation program}

Three aspects of the prototype wall behavior were monitored by field instrumentation both during and after wall construction. Specifically, the monitoring program included:

- horizontal displacements within the reinforcement layers measured using mechanical extensometers (telltales);

- face displacements measured by external surveying; and

- vertical settlements measured by magnetic extensometers.

The instrumentation layout of prototype wall 1 is shown in Figure 8 .

The mechanical extensometers consist of $0.35 \mathrm{~mm}$ diameter stainless steel wires, running inside nylon tubes, which were used to reduce friction and to protect the wires. The wires were connected to the geotextiles using staples. Figure 1 shows the vertical shaft, constructed at the back of the wall, which was used to collect readings from the mechanical extensometers. One end of the telltale is fixed to the geotextile, and the free end is located in the vertical shaft. The free end of the telltale is attached to a hanging weight, which allows measurement of the displacements (Figure 9). The free ends of the telltales were located in a shaft constructed behind the prototype wall. Measurements were made using a digital caliper with a resolution of $0.01 \mathrm{~mm}$.

Displacements at the wall face of the prototype were also measured during and after wall construction by the mechanical extensometer attached to the face of each reinforcement layer. In addition, external displacements of the prototype wall face were surveyed during and after construction by measuring the distance of points placed at the center of each layer to a fixed reference point. Figure 10 shows the survey measurement of prototype wall 1 and external reference post. Survey measurements allowed a resolution of $1 \mathrm{~mm}$. A total of five reinforcement layers were instrumented with seven mechanical extensometers each, as shown in Figure 8. 


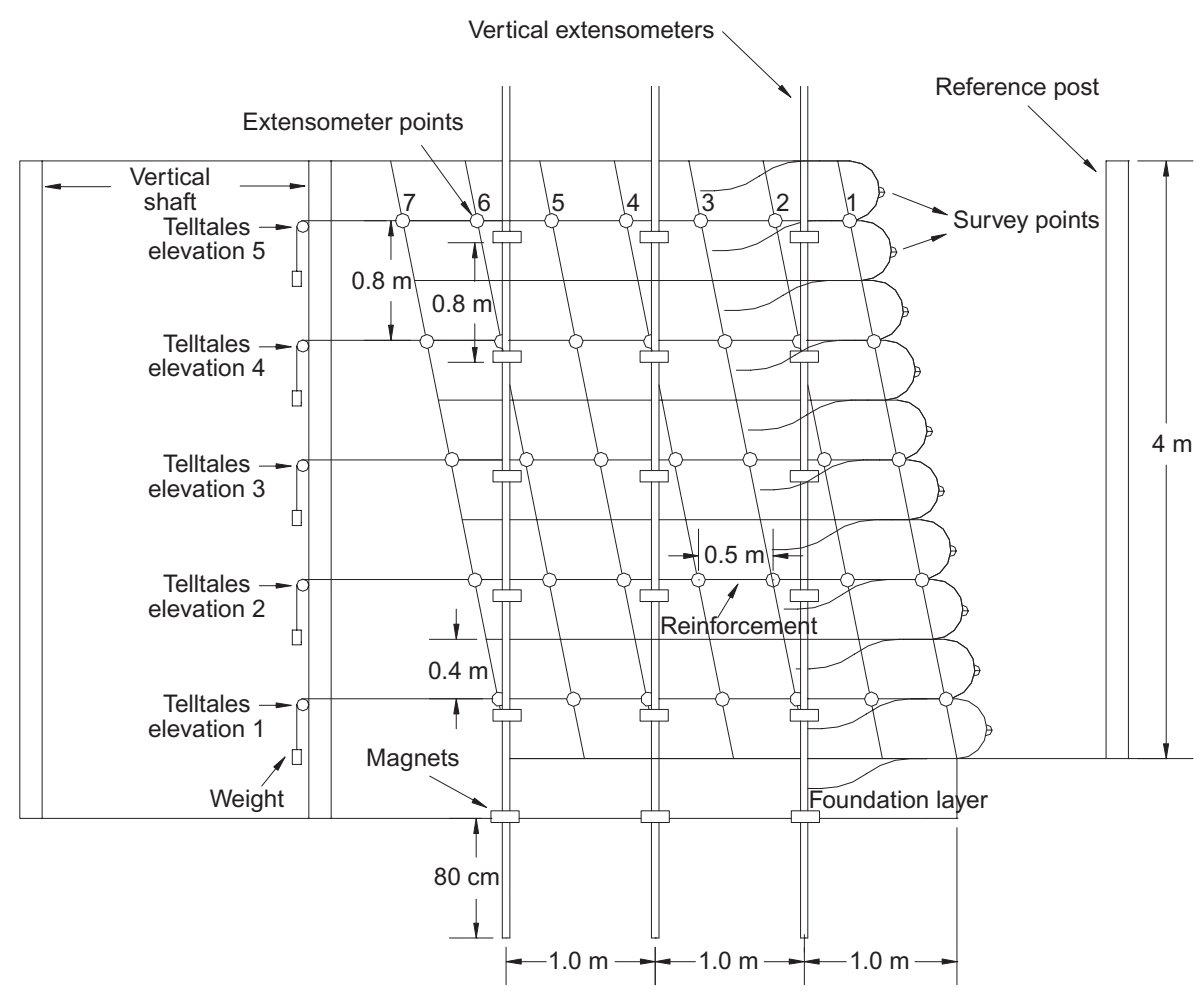

Figure 8. Instrumentation plan of prototype wall 1

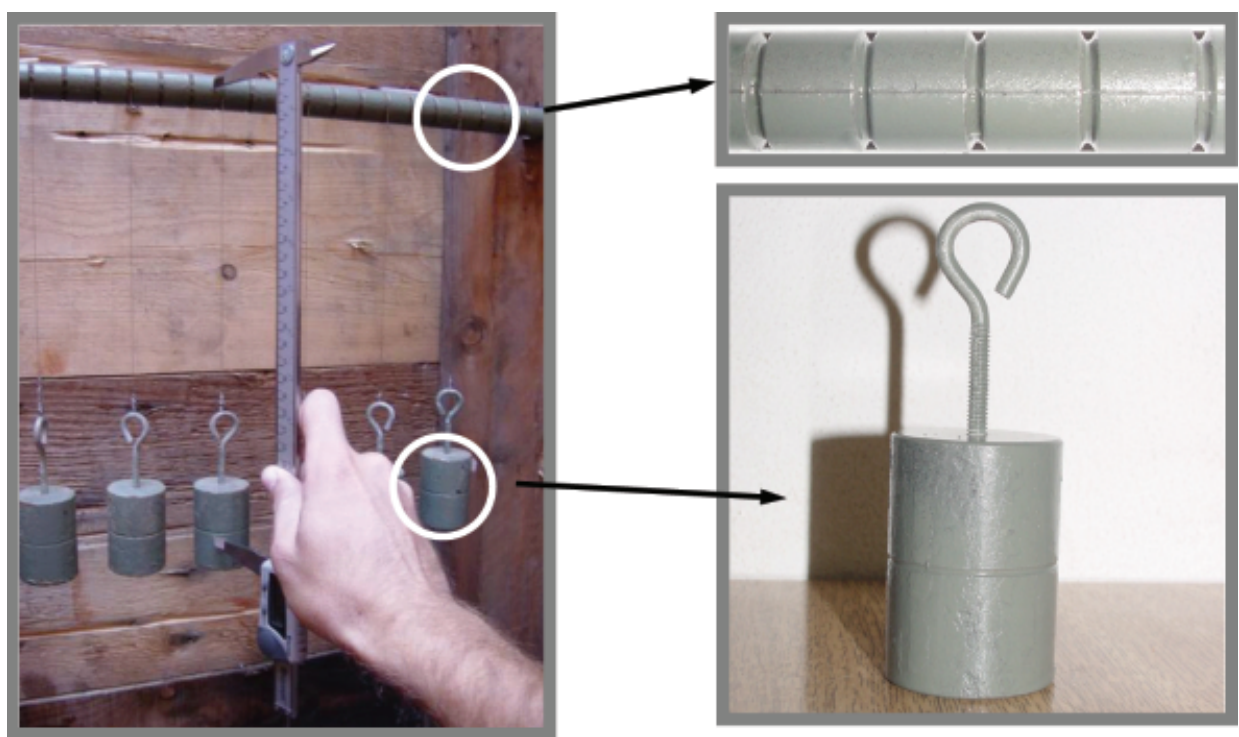

(a)

(b)

Figure 9. View of telltale free end: (a) measuring displacement; (b) telltale end

Magnetic extensometers were designed and constructed as part of this study to measure vertical settlements within the backfill (Figure 11). The extensometers are composed of magnetic plates attached to PVC pipes. Magnets were attached to the center of each $0.20 \mathrm{~m}$ square plate to register the position of a vertical probe. Measurements were conducted by introducing an aluminum probe with an electronic measuring device (reed switch) installed in its tip. When the probe approaches the magnet, an electric circuit closes, activating a sound indicator. The measurements were taken at the beginning and ending of the sound indicator, which correspond to the top and bottom faces of the magnet. The resolution of the magnetic extensometer is $1 \mathrm{~mm}$.

\section{INSTRUMENTATION RESULTS}

Preliminary instrumentation results obtained from prototype wall 1 illustrate the baseline response of the structures constructed as part of this investigation. In addition, results of this prototype wall will be useful in conducting parametric analyses. These comparisons are beyond the scope of this paper, but include evaluation of different soil types (prototype walls 3 and 5), reinforcement types 


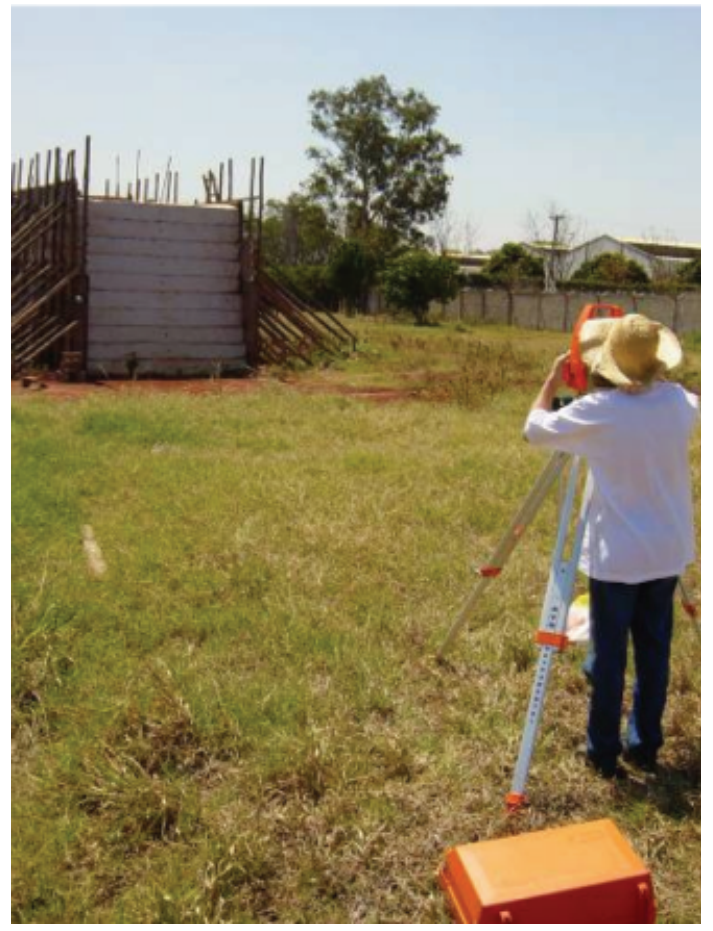

(a)

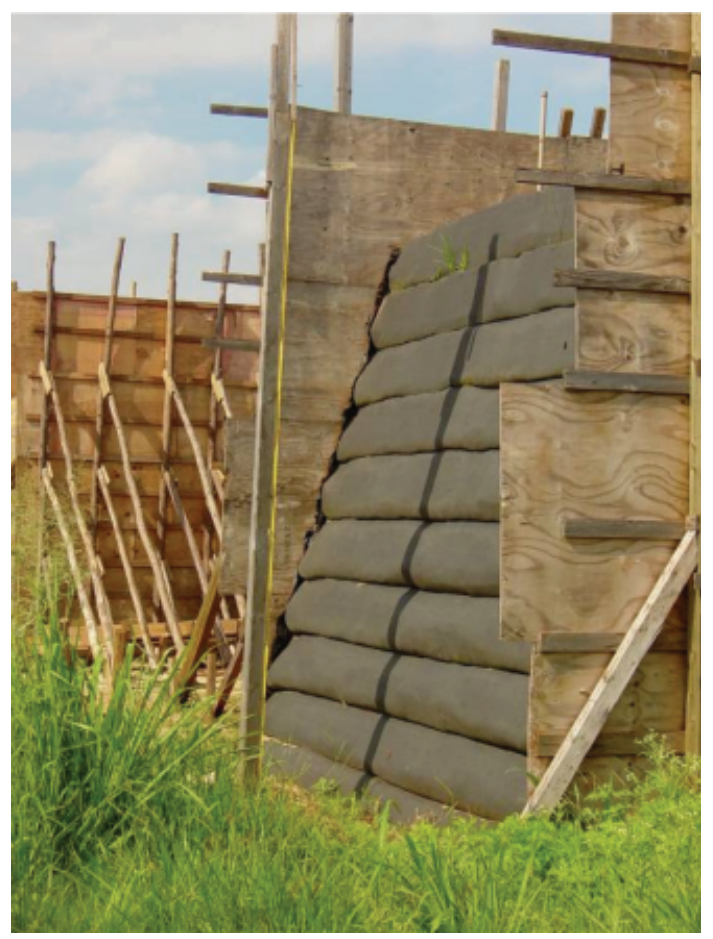

(b)

Figure 10. Measurement of face displacements: (a) survey measurement; (b) external reference post

(prototype walls 7 and 8), and the internal geometry of the structures (prototype wall 2).

\subsection{Horizontal displacements within the reinforcements}

Figures $12 \mathrm{~b}$ to $12 \mathrm{f}$ show the time history of the horizontal displacements measured by extensometers along five of the reinforcement layers. The precipitation recorded at the site during this period is also shown, in Figure 12a. The initial reading reported in each figure (at time 1 hour) represents the displacement at the end of construction.

The overall displacements reached a maximum value of $13.0 \mathrm{~mm}$ at mid-height of the prototype wall. The instrumented layers presented intermediate maximum displacements of 6.0 and $8.0 \mathrm{~mm}$ at intermediate elevations 2 $(1.2 \mathrm{~m})$ and $4(2.8 \mathrm{~m})$, respectively. The top and lower reinforcement layers showed the smallest maximum displacements $(2.5 \mathrm{~mm}$ and $5.0 \mathrm{~mm}$ at elevations $1(0.4 \mathrm{~m})$ and $5(3.6 \mathrm{~m})$, respectively).

The largest horizontal displacements occurred in the vicinity of the face of the prototype wall (see distance from facing $0.0 \mathrm{~m}$ in Figures $12 \mathrm{~b}$ to $12 \mathrm{f}$ ), and increased with time. Most of these displacements were observed to take place after the rains that occur during the summer season in Brazil. For example, during a period of rain of $1 \mathrm{~mm} /$ day, the displacements in layer 3 increased from 5 to $9 \mathrm{~mm}$ (i.e. at a rate of $0.7 \mathrm{~mm} / \mathrm{month}$ ). However, during a period of rain of approximately $10 \mathrm{~mm} /$ day, the displacement rate increased from 9 to $13 \mathrm{~mm}$ (i.e. at a rate of $1.0 \mathrm{~mm} / \mathrm{month}$ ).

In order to facilitate data interpretation, the extensometers were aligned in profiles parallel to the face during installation to facilitate evaluation of the horizontal displacements. Figure 13 shows the displacement distribution patterns, using the same data as presented in Figure 12, but illustrating the outward movements. The displacements shown in Figure 13 were measured in relation to a fixed location at the back of the prototype wall. Accordingly, they represent the displacements measured directly using the telltales. As expected, the largest displacements occurred close to the wall face, reaching $13 \mathrm{~mm}$ at midheight of the prototype wall. The second profile of extensometer points, located $0.5 \mathrm{~m}$ from the wall face, shows a displacement pattern similar to the first profile (located at the facing), with the maximum displacements occurring at the same elevation $(2.0 \mathrm{~m})$.

In the two profiles closer to the prototype wall face, the displacements decrease towards the base and to the top of the structure, reaching negligible values at both elevations. The subsequent profiles (from $1.0 \mathrm{~m}$ from the face to the back) no longer show a pattern of maximum displacement at mid-height of the prototype wall. Specifically, the displacement results show significantly smaller values, which did not exceed $2 \mathrm{~mm}$ at any location.

\subsection{Face displacements}

The face displacements measured by external survey were larger than those measured using extensometers at the facing (Figure 14). These discrepancies can be attributed to localized displacements due to soil bulging at the flexible facing, which occurred during construction. It should be noted that survey measurements were made in the middle of each layer, whereas extensometer measurements were made at the reinforcement layer.

However, both external (survey) and internal (extensometer) measurements showed similar patterns, with maximum displacement at mid-height of the wall, and decreasing values towards the base and the top of the structure. The maximum displacement measured using 


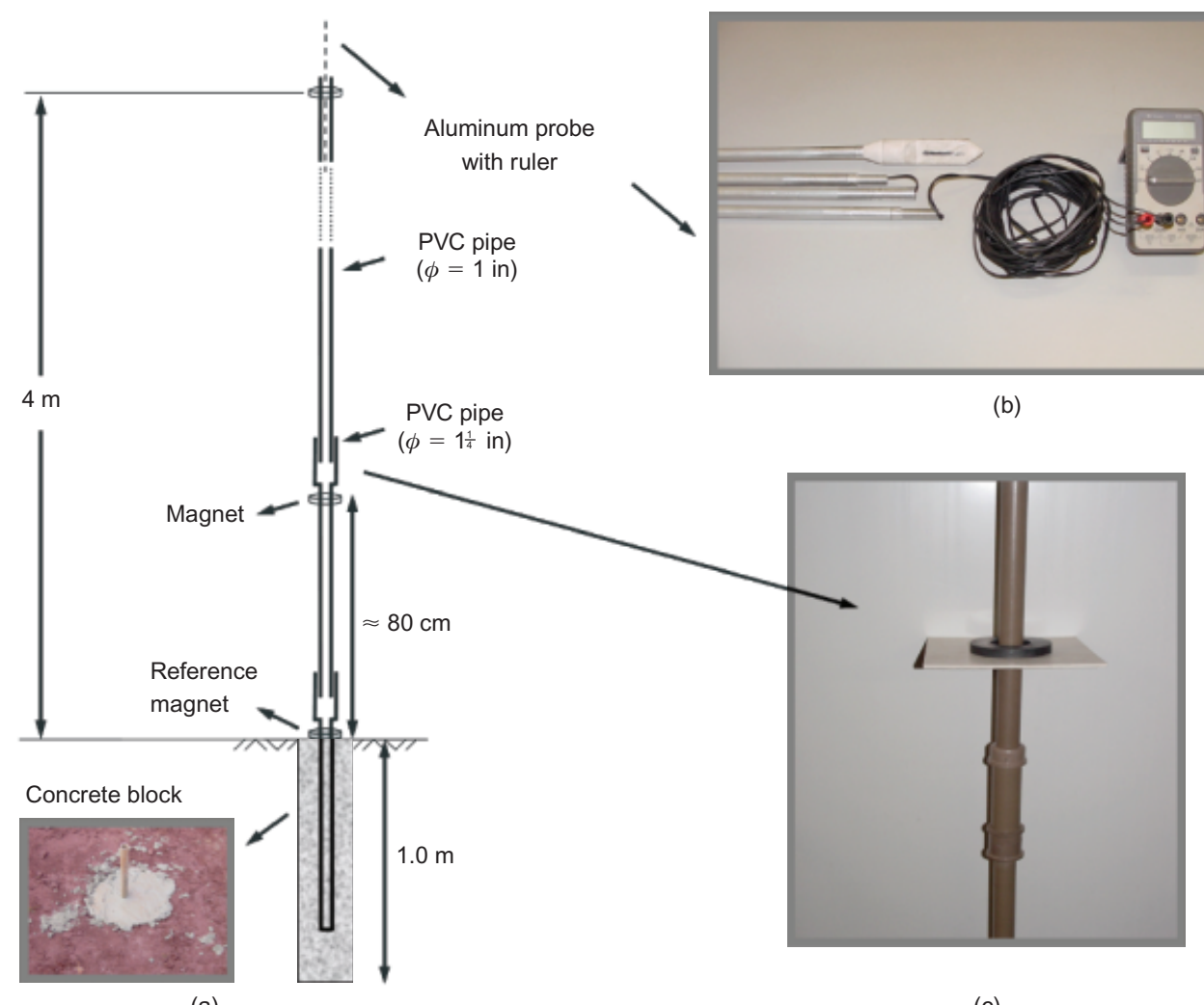

(a)

(c)

Figure 11. Vertical displacement measurement: (a) magnetic extensometer equipment; (b) aluminum probe; (c) PVC pipe with magnet

extensometers at the end of the construction was $5 \mathrm{~mm}$, whereas the maximum displacement measured by external survey was $58 \mathrm{~mm}$. After 203 days, the maximum displacement increased to $13 \mathrm{~mm}$ (extensometer readings) and $65 \mathrm{~mm}$ (survey measurements), respectively. That is, both survey and extensometer post-construction displacements showed a consistent maximum value of approximately $7 \mathrm{~mm}$.

Figure 15a shows the face displacements measured by extensometers at different times after construction, and Figure $15 \mathrm{~b}$ illustrates the post-construction displacements at the face. These results show that the location of the largest displacements observed during construction (midheight of the wall) is the same as the location of the largest post-construction displacements. These results are consistent with those obtained by Zornberg et al. (1998) using centrifuge models, who reported that the maximum strains for steep slopes occur towards the mid-height of the structure.

\section{EVALUATION OF REINFORCEMENT STRAINS AND LOADS}

\subsection{Preliminary evaluation of reinforcement strains}

The reinforcement strains were initially calculated by dividing the relative displacement between two consecutive extensometer points by the initial distance between the extensometer points. Figure 16 shows the reinforcement strains. Although the wall was designed using reduction factors of unity, the horizontal reinforcement strains that occurred during construction were comparatively small, with the largest values occurring towards the face of the structure. The largest strain values occurred at approximately mid-height of the prototype wall, with a maximum value calculated at the end of construction of $0.8 \%$. Additional post-construction strains occurred during the weeks following construction, reaching a maximum value of $1.3 \%$ after 203 days. The strains induced near the face took place mainly during construction, with local bulging observed to develop after removing the wood lagging board supports.

Figure 17 shows the development of the maximum strains in the instrumented reinforcement, with precipitation data shown as a reference in the same graph. The precipitation data show that the prototype walls were subjected to heavy rain, which led to water infiltration into the reinforced backfill. A decrease in soil suction and an increase in the weight of the soil are responsible for the slight post-construction increases in reinforcement strains.

Comparison of field post-construction strains with creep laboratory test results indicates that the strain rates (slopes of the strain curves) registered in the prototype wall were considerably smaller than the rate obtained from laboratory tests. The overall strains were small, which is notable, particularly considering that the prototype wall was designed using reduction factors of 1.0. The results suggest that the method used in the prototype wall design is conservative.

However, it should be noted that other factors that may have contributed to the comparatively small strains were not taken into consideration in the design. These factors 


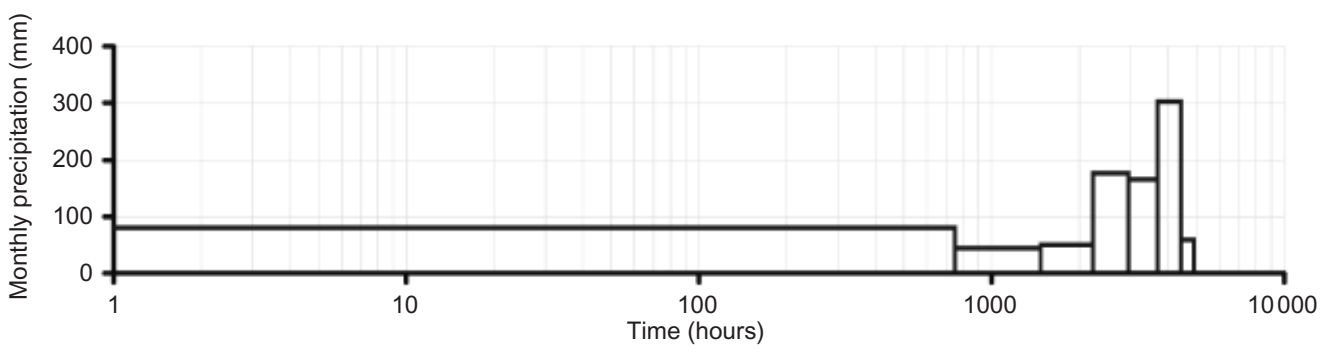

(a)

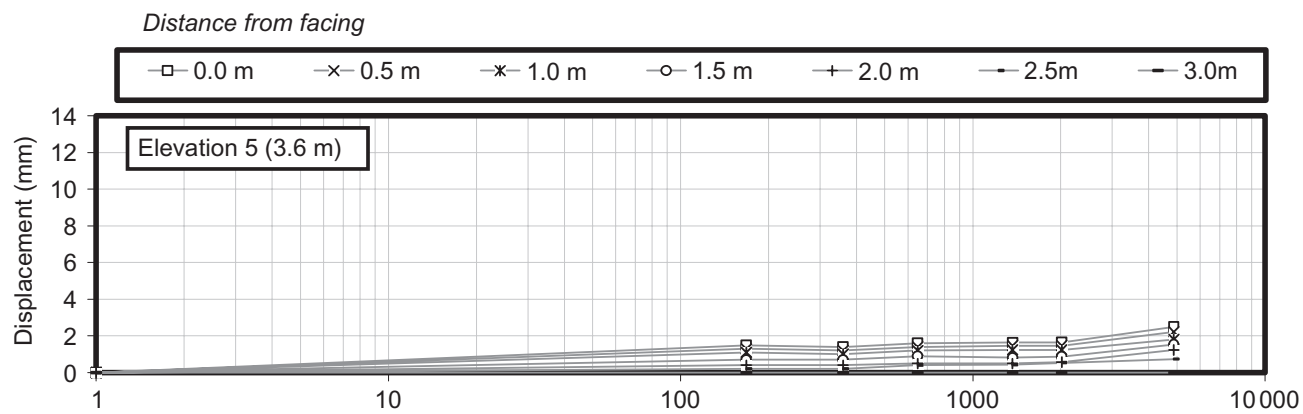

(b)

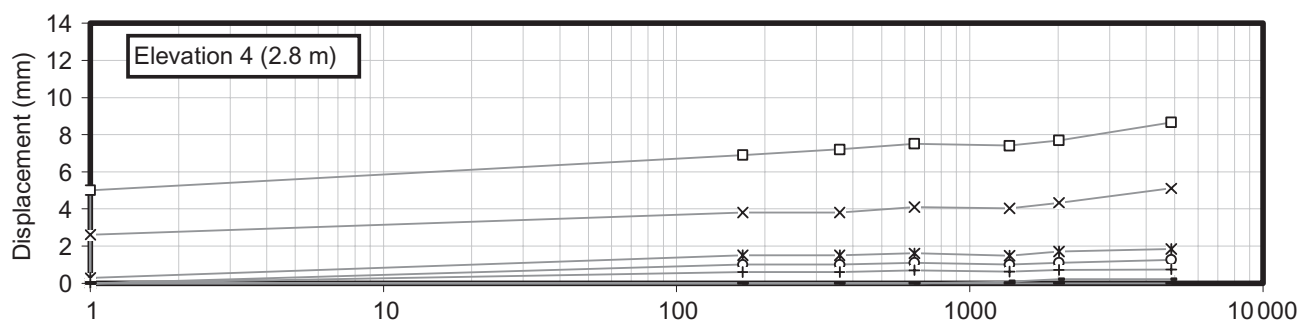

(c)

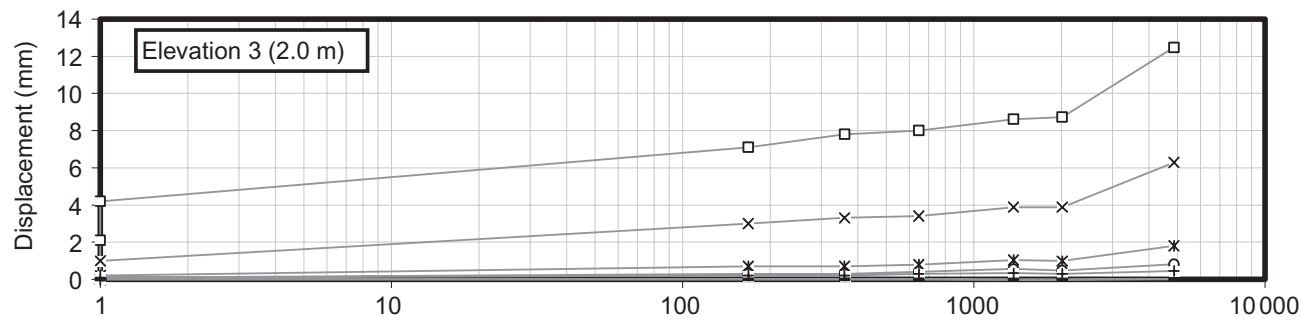

(d)

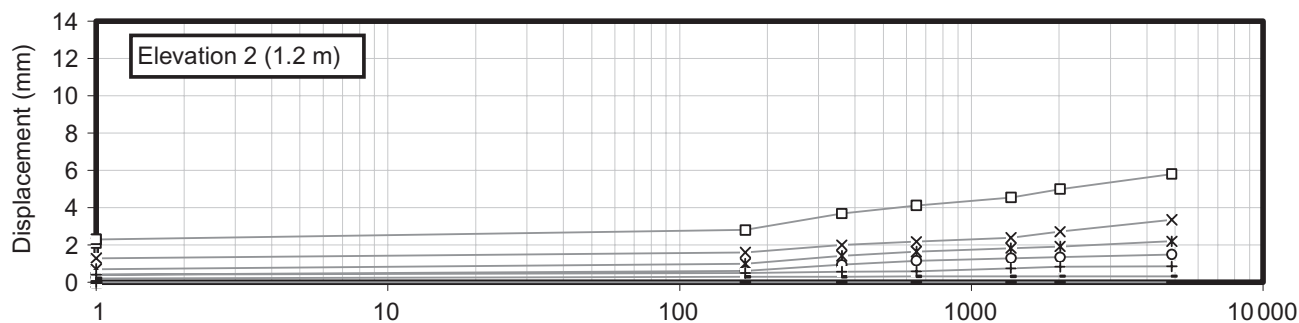

(e)

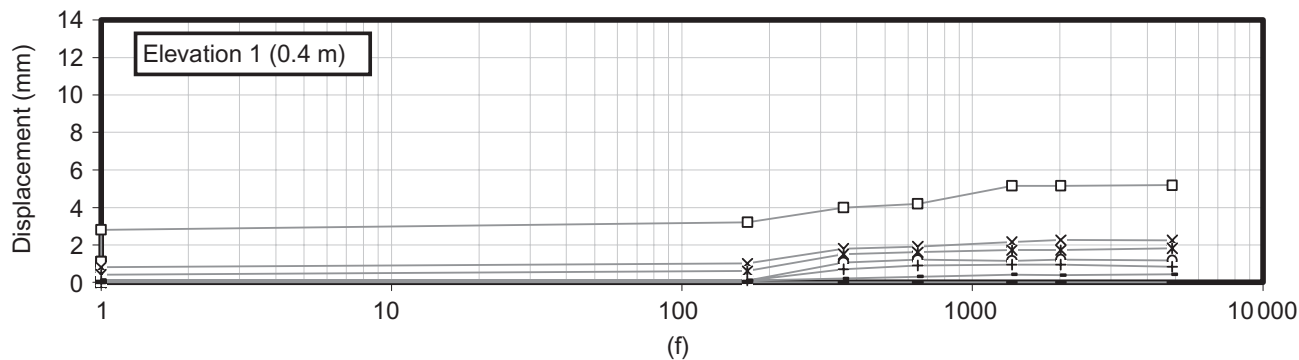

Figure 12. Time record of precipitation and reinforcement displacements measured by extensometers: (a) precipitation; (b) elevation 1; (c) elevation 2; (d) elevation 3; (e) elevation 4; (f) elevation 5 


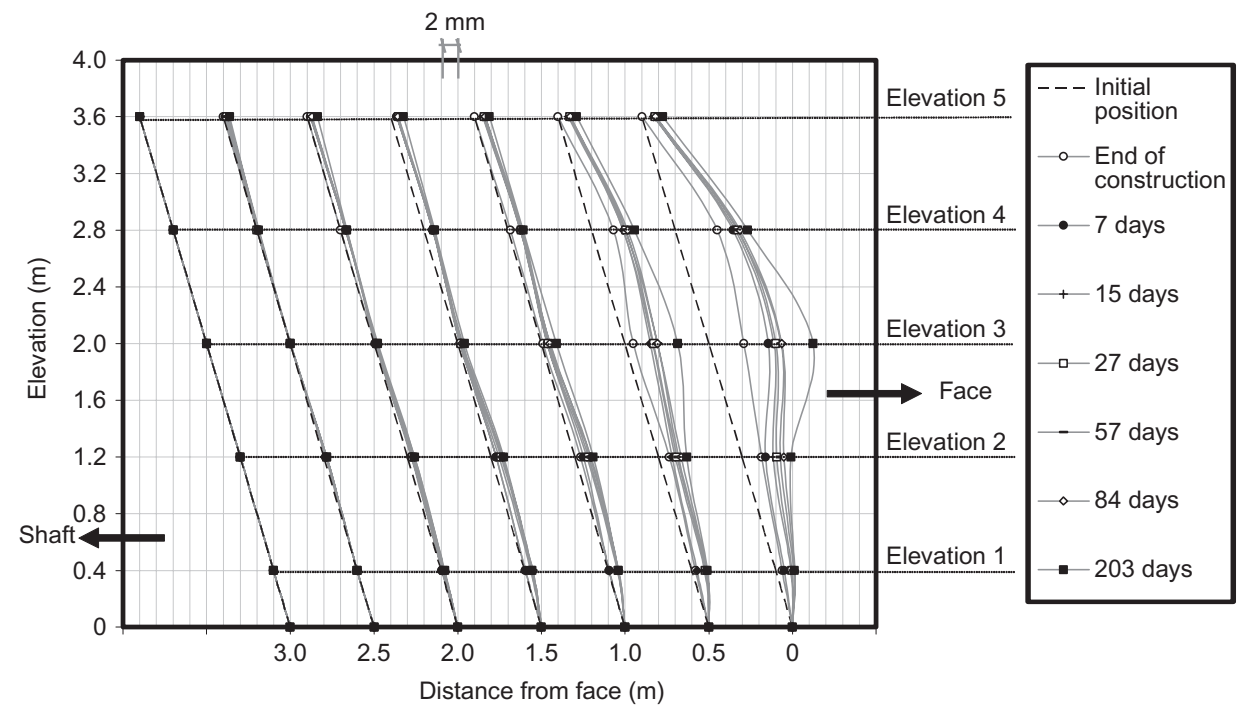

Figure 13. Data of end bearing extensometers aligned in quasi-vertical profiles

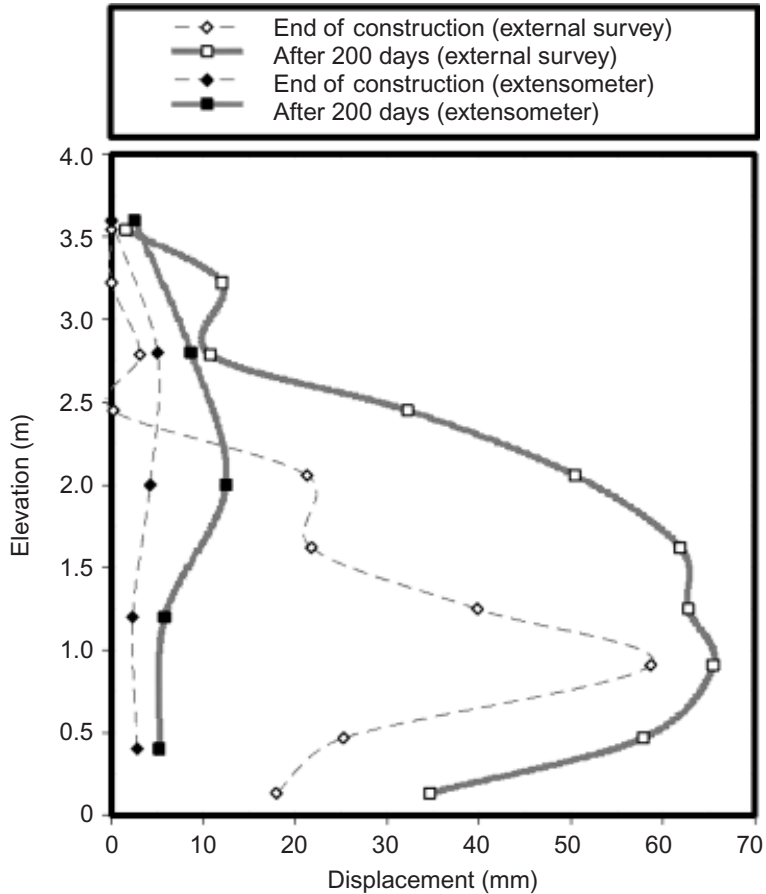

Figure 14. Face displacements measured by external survey and extensometer readings

include the contribution of suction in the unsaturated backfill soil, the effect of soil confinement on the stiffness of the nonwoven geotextile reinforcement, and the contribution of geotextile overlaps, which effectively doubled the number of geotextile layers in the vicinity of the wall face.

\subsection{Use of sigmoid curves for determination of displacement trends}

As mentioned earlier, geotextile strain values were initially estimated by calculating the relative movements between extensometers and dividing them by the distance between measuring points. However, the use of raw extensometer displacement data to perform these calculations often led to erratic reinforcement strain distributions. This is because minor scatter in the displacement trend results in major oscillations in the calculated strains. Consequently, the raw extensometer displacement information was also evaluated by fitting the data to a monotonically increasing curve in order better to define the strain distribution (Zornberg and Arriaga 2003).

This approach allows direct determination of the magnitude and location of the maximum reinforcement strain, even in the case of very small displacements. The expression used to fit the extensometer displacements is a sigmoid curve defined by

$$
d=\frac{1}{a+b e^{-c x}}
$$

where $d$ is the displacement of each point relative to the face of the prototype, $x$ is the extensometer point, $e$ is the base of natural logarithms, and $a, b$ and $c$ are the fitting parameters. The main characteristics of the sigmoid function are shown in Figure 18.

After fitting the displacement data to sigmoid curves, the geotextile strain distribution could be defined as the derivative of the sigmoid function. The peak strain value and its location from the slope face in each reinforcement layer can be determined analytically using the parameters $a, b$ and $c$ that fit the displacement data. The expressions for maximum strain and its location are

$$
\begin{aligned}
\varepsilon_{\max } & =\frac{c}{4 a} \\
x_{\max } & =\frac{1}{c} \ln \left(\frac{b}{a}\right)
\end{aligned}
$$

where $\varepsilon_{\max }$ is the magnitude of the peak strain in each reinforcement and $x_{\max }$ is the location, measured from the slope face, where the peak strain occurs.

Figure 19 shows the horizontal geotextile displacements, relative to the wall face, obtained from the 


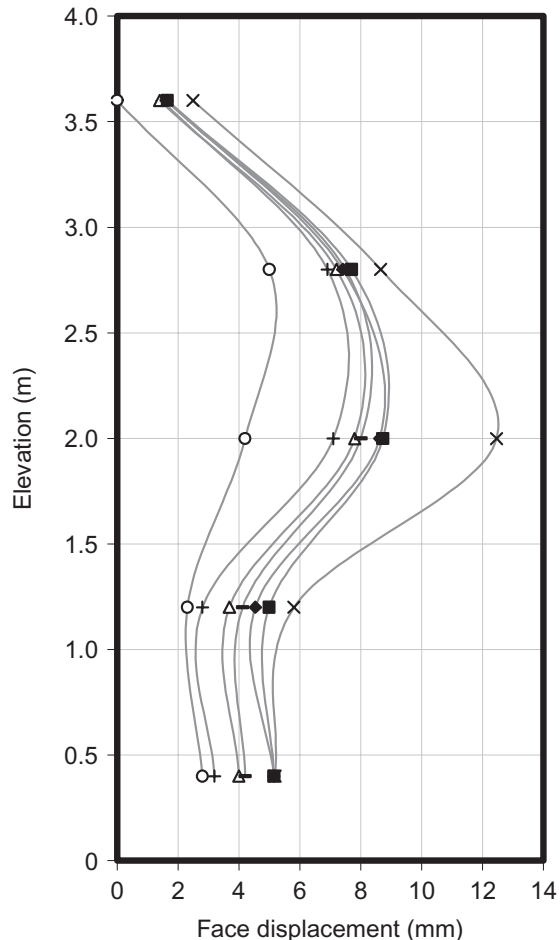

(a)

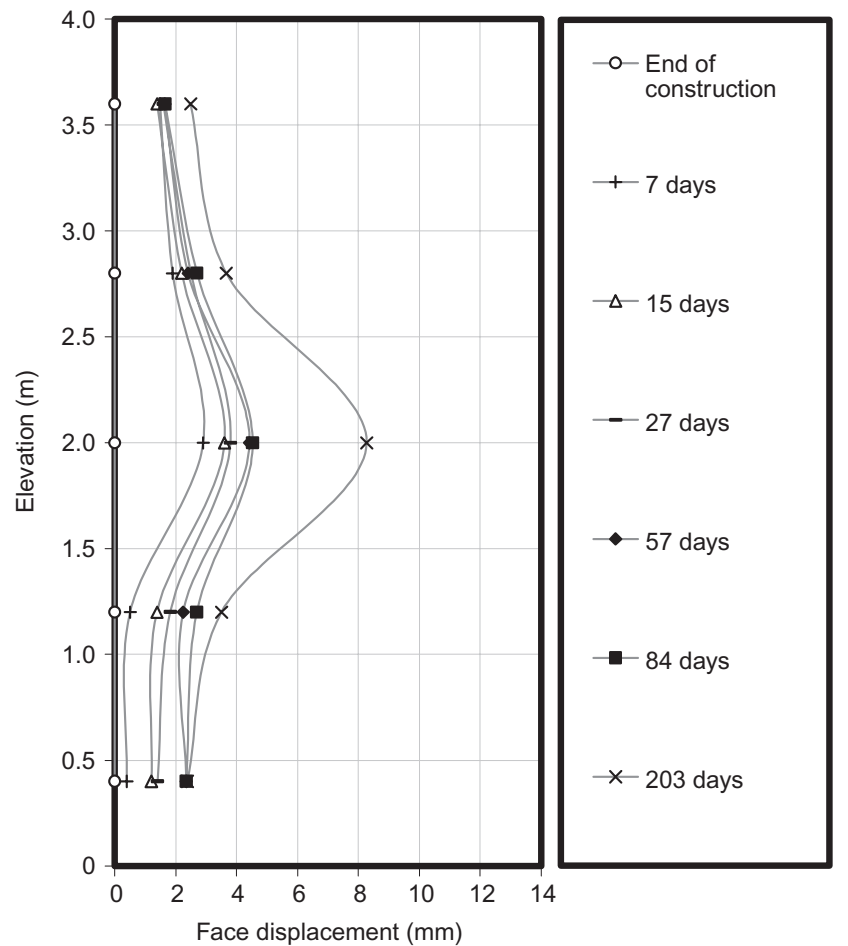

(b)

Figure 15. Face displacements measured by extensometers: (a) Total displacements, b) Post-construction displacements

extensometers, along with the superimposed sigmoid curves defined by fitting the raw displacement data. The solid points in the figure represent the displacement registered directly with the extensometers, and the lines correspond to the sigmoid curves. Figure 20 shows the reinforcement strains calculated using the sigmoid fitted curve approach. Although adding significant fluctuations to the strain distributions, preliminary calculations done using the raw relative movements between extensometer points provide similar trends to those obtained by fitting the raw data to a sigmoid curve. The strain distribution shows small values in the vicinity of the prototype wall face, a clear strain peak, and a negligible strain towards the end of the reinforcement layer. Although the maximum strain values are very similar to those calculated directly, the locus of maximum strain is better defined when using sigmoid curves in the analysis.

\section{ADDITIONAL ASPECTS OF THE MONITORED WALL PERFORMANCE}

\subsection{Potential failure surface}

The location of maximum tensile strain in reinforcements has been reported to be the location of the potential failure surface (Zornberg et al. 1997). Figure 21 shows the tensile strain distribution of prototype wall 1 , with an indication of the potential failure surfaces, as defined by the strain calculated directly and using the sigmoid curves. The locations of maximum reinforcement strain show evidence that the potential slip surface starts at the toe of the slope and propagates into the soil mass, following a pattern consistent with that typically assumed in design.
The proximity of the potential failure surface to the prototype wall face can be attributed to the observed sagging of the facing. Accordingly, a surficial stability problem, rather than a deep shear surface, could govern the performance. Yet, since this is the region of the additional facing overlaps, there are twice as many geotextile layers in this zone, which provide additional stabilization at the surface.

\subsection{Calculation of $T_{\max }$ using the $K$-stiffness method}

The K-stiffness method (Allen and Bathurst 2003; Bathurst et al. 2005) was used to estimate the tensile forces in the reinforcements using the measured strain values. This methodology considers the stiffness of all wall components relative to the soil stiffness to estimate the distribution and magnitude of the maximum tensile load, $T_{\max }$, in each reinforcement layer. The method is semi-empirical in nature, as it was calibrated using monitored case histories to predict the reinforcement loads. Consequently, the results obtained in this study provide additional information suitable for validation and/ or refinement of the K-stiffness method, particularly considering that little information is available on the use of geotextiles as reinforcement.

The K-stiffness method was reported to provide a reasonably accurate prediction of wall performance under working stress conditions (Allen and Bathurst 2003; Bathurst et al. 2005). This method was reported to provide significantly more accurate estimates of reinforcement loads and strains in reinforced soil walls than previous design methodologies.

The peak load in each reinforcement layer, $T_{\max }$, can be calculated using the K-stiffness method as follows: 


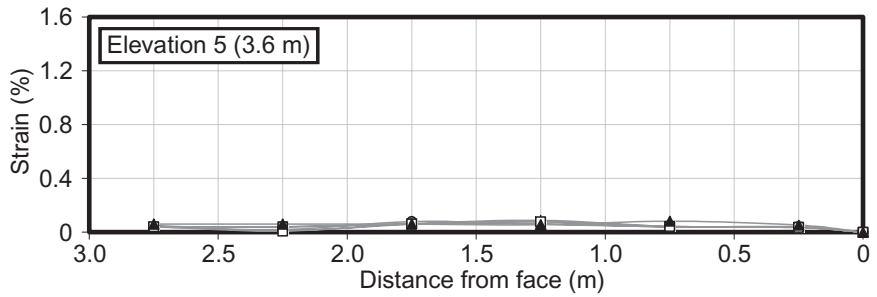

$-\square-7$ days

$\triangle-15$ days

- 27 days

+57 days

- 84 days

-203 days

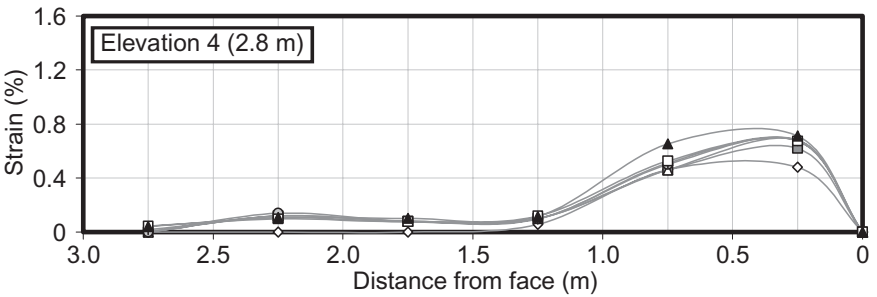

$\diamond$ End of construction

$\square-7$ days

15 days

27 days

days

84 days

- 203 days

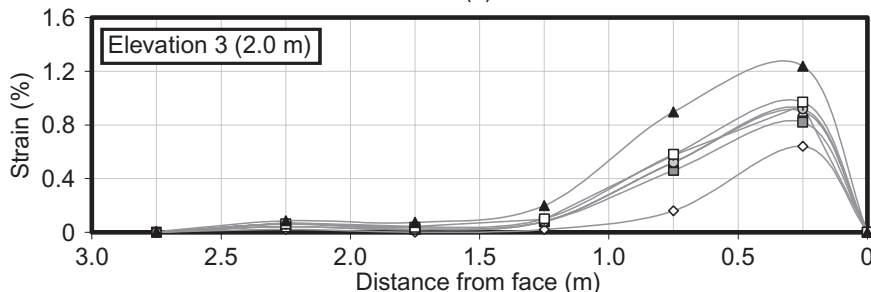

$\checkmark$-End of construction

$\triangle 15$ days

-27 days

+57 days

$\square-84$ days

-203 days

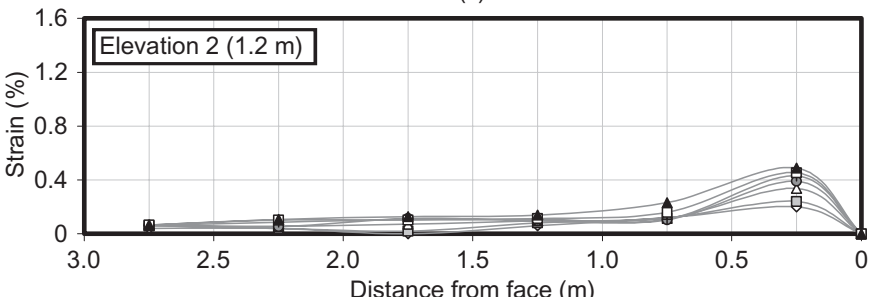

$\checkmark$ End of construction

$\square-7$ days

$\triangle 15$ days

$0-27$ days

+57 days

$\square-84$ days

$\_203$ days

(d)

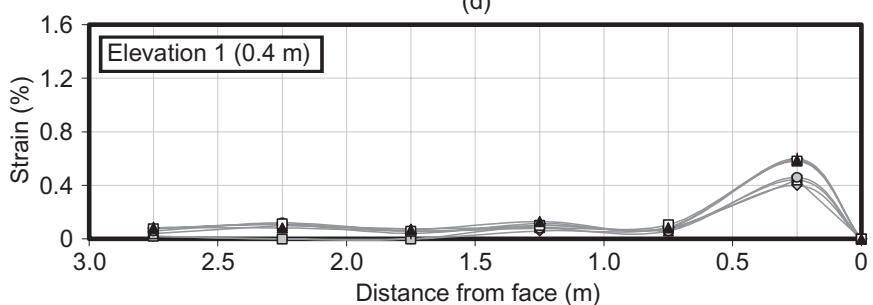

$\diamond$ End of constrction

$\square-7$ days

$\triangle 15$ days

- -27 days

+57 days

- 84 days

$\_203$ days

(e)

Figure 16. Reinforcement strains: (a) elevation 1; (b) elevation 2; (c) elevation 3; (d) elevation 4; (e) elevation 5
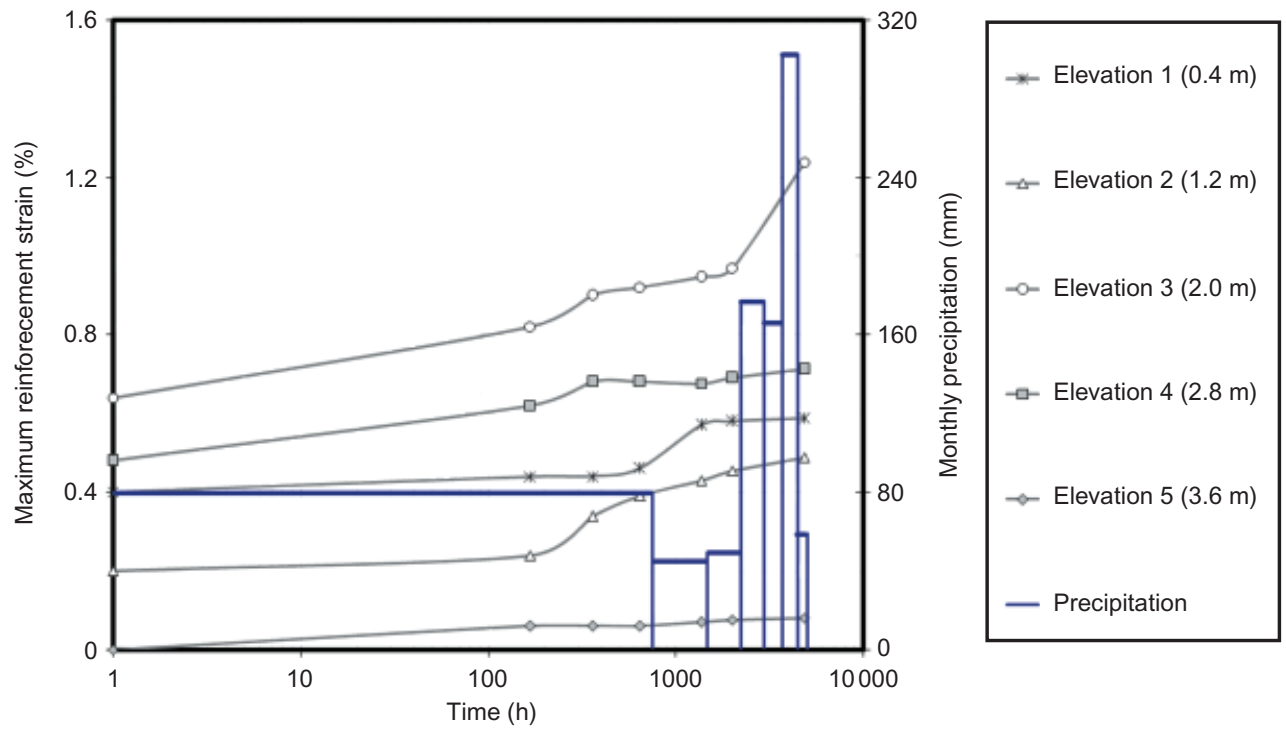

Figure 17. Maximum strains in each instrumented reinforcement 


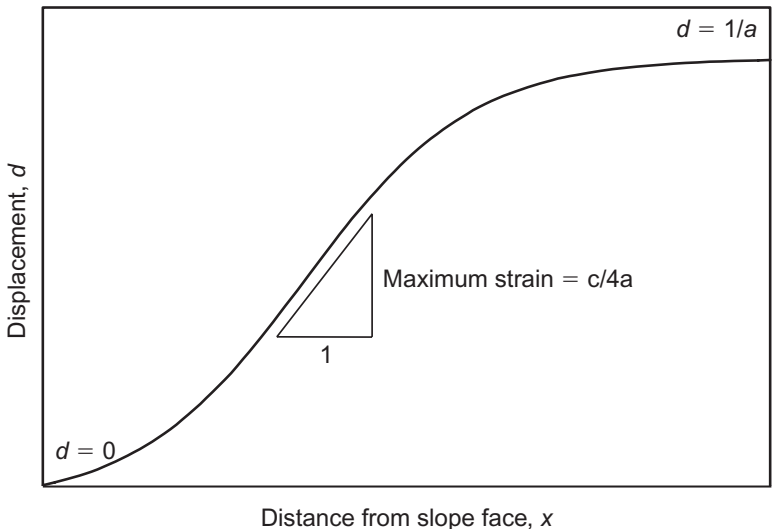

Figure 18. Sigmoid function used to fit extensometer displacement data

$$
\begin{aligned}
& T_{\max }= \\
& \quad 0.5 S_{\mathrm{v}} K \gamma(H+S) D_{\mathrm{tmax}} \Phi_{\text {local }} \Phi_{\mathrm{fb}} \Phi_{\mathrm{fs}} 0.27\left(\frac{S_{\text {global }}}{P_{\mathrm{a}}}\right)^{0.24}
\end{aligned}
$$

where $S_{\mathrm{v}}$ is the tributary area, assumed equivalent to the average vertical spacing of the reinforcement at each layer location; $\phi$ is the friction angle of the soil; $K$ is the lateral pressure coefficient for the reinforced backfill, determined approximately as $K=1-\sin \phi ; H$ is the vertical wall height at the face; $S$ is the average soil surcharge height above the prototype wall top; and $D_{\text {tmax }}$ is a distribution factor. $D_{\text {tmax }}$ is used to estimate $T_{\max }$ for each layer as a function of its depth below the prototype wall relative to the maximum tension value within the prototype wall, $T_{\mathrm{mxmx}}$ (Figure 22). $\Phi_{\mathrm{fs}}$ is the facing stiffness factor (equal to 1.0 for wrapped faced walls), and $P_{\mathrm{a}}$ is the atmospheric pressure $(101 \mathrm{kPa}) . S_{\text {global }}$ is the global reinforcement stiffness, defined as

$$
S_{\text {global }}=\frac{J_{\text {ave }}}{(H / n)}=\frac{\sum_{i=1}^{n} J_{i}}{H}
$$

where $J_{\text {ave }}$ is the average stiffness of all reinforcement layers within the entire wall section, $J_{i}$ is the stiffness of an individual reinforcement layer, $H$ is the total wall height, and $n$ is the number of reinforcement layers within the entire wall section.

Considering that the same geotextile was used in all the layers $(J=13.00 \mathrm{kN} / \mathrm{m})$, the calculated $S_{\text {global }}$ is $32.50 \mathrm{kN} / \mathrm{m}^{2}$. $\Phi_{\text {local }}$ is the global reinforcement stiffness, defined as

$$
\Phi_{\text {local }}=\left(\frac{S_{\text {local }}}{S_{\text {global }}}\right)^{a}
$$

where $a$ is a coefficient that is also a function of stiffness. The coefficient $a$ was adopted as 1.0 for geosynthetic walls, as suggested by Allen and Bathurst (2003) and Bathurst et al. (2005).

The local stiffness $\left(S_{\text {local }}\right)$ considers the stiffness and reinforcement density at a given layer, which is calculated as

$$
\begin{aligned}
& S_{\text {local }}=\frac{J}{S_{\mathrm{v}}} \\
& \Phi_{\text {local }}=\left(\frac{S_{\text {local }}}{S_{\text {global }}}\right)^{a}
\end{aligned}
$$

For prototype wall 1 , with a vertical spacing $S_{\mathrm{v}}=$ $0.4 \mathrm{~m}, \mathrm{~S}_{\text {local }}=32.50 \mathrm{kN} / \mathrm{m}^{2}$ and $\Phi_{\text {local }}=1.0$. The wall face batter factor, $\Phi_{\mathrm{fb}}$, which accounts for the influence of the reduced soil weight on reinforcement loads, is determined from

$$
\Phi_{\mathrm{fb}}=\left(\frac{K_{\mathrm{abh}}}{K_{\mathrm{avh}}}\right)^{d}
$$

where $K_{\mathrm{abh}}$ is the horizontal component of the active earth pressure coefficient accounting for wall face batter, $K_{\text {avh }}$ is the horizontal component of the active earth pressure coefficient, $d$ is a constant coefficient.

Figure 23 presents the profile of $T_{\max }$ values defined using the K-stiffness method. The same figure shows the $T_{\max }$ values derived by using the maximum strain values defined using the sigmoid-fitted curves method. Based on confined tests results published by Kamiji (2006) and Gomes (1992), the confined stiffness of the tested geotextile was estimated as $65 \mathrm{kN} / \mathrm{m}$, which is five times larger than the unconfined stiffness.

Figure 23 shows that the $T_{\max }$ values defined using the measured strain results from prototype wall 1 show a pattern consistent with those predicted using the Kstiffness method, although the actual values are smaller. However, it should be noted that suction in the unsaturated backfill was not accounted for in the evaluation. Consequently, for practical purposes, the K-stiffness method is deemed to provide a good estimate of the values obtained using measured results.

\subsection{Vertical settlements}

The vertical displacements within the backfill were obtained by magnetic extensometers installed within the reinforced zone. Figure 24 shows the time history of the vertical displacements measured within the backfill using the magnetic extensometers. The maximum settlement measured at the end of the construction equals $5 \mathrm{~mm}$, and is located close to the face of the prototype wall. After 203 days the post-construction settlements increased by only $1 \mathrm{~mm}$, reaching $6 \mathrm{~mm}$ at the magnets located at the mid-height of the wall (magnets 3 and 4 in Figure 24).

The foundation settlements were also registered using vertical magnetic extensometers placed within the foundation soil. Figure 25 shows the settlements at the foundation level from the beginning of construction and up to 84 days after construction. The results indicate that the largest displacements occurred in the middle of the reinforced zone.

Large displacements of the foundation were expected because of the compressible foundation soil, as quantified by the low SPT test results $(N=2)$. The largest displacements occurred during construction (approximately 91\% 


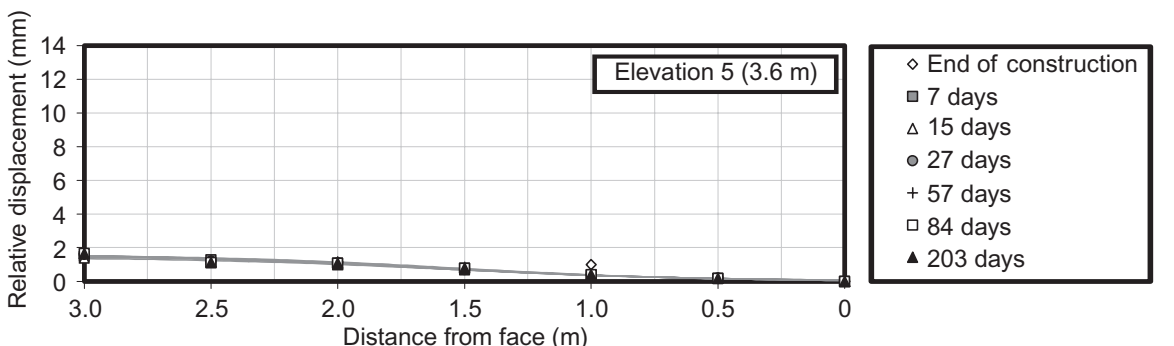

(a)

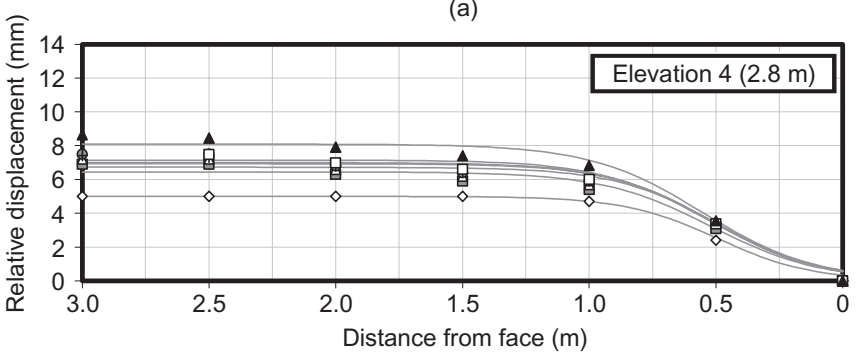

\begin{tabular}{|l|}
\hline$\diamond$ End of construction \\
$\square 7$ days \\
$\Delta 15$ days \\
$\diamond 27$ days \\
+57 days \\
$\square 84$ days \\
$\mathbf{\Delta} 203$ days \\
\hline
\end{tabular}

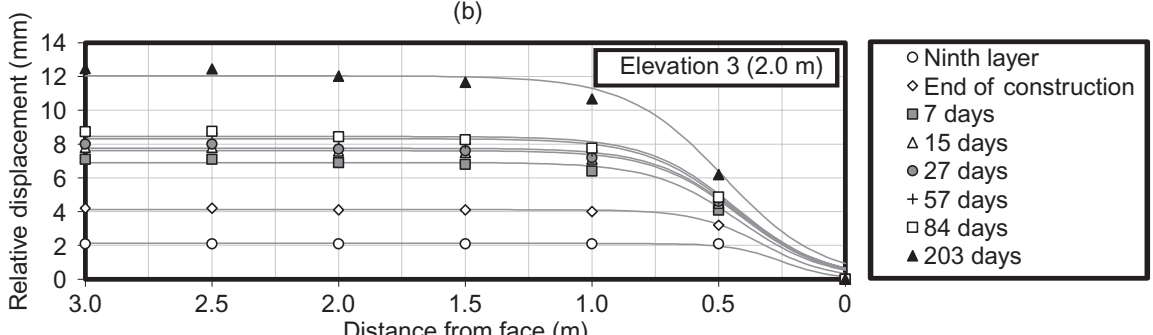

(c)
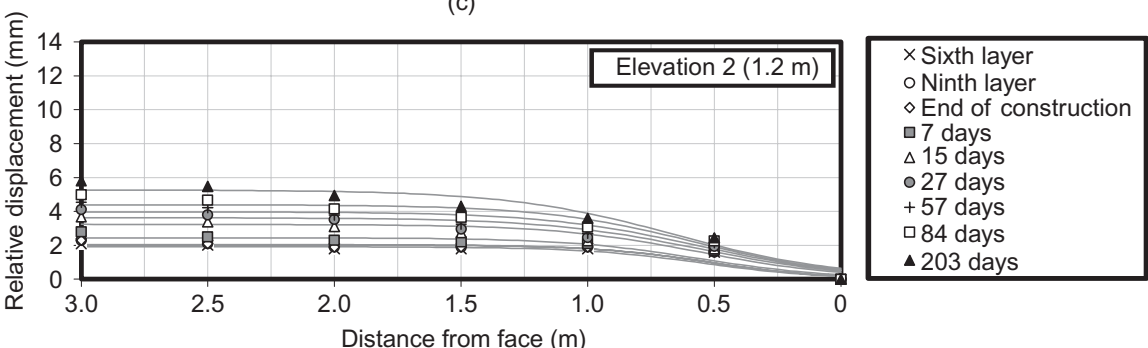

(d)

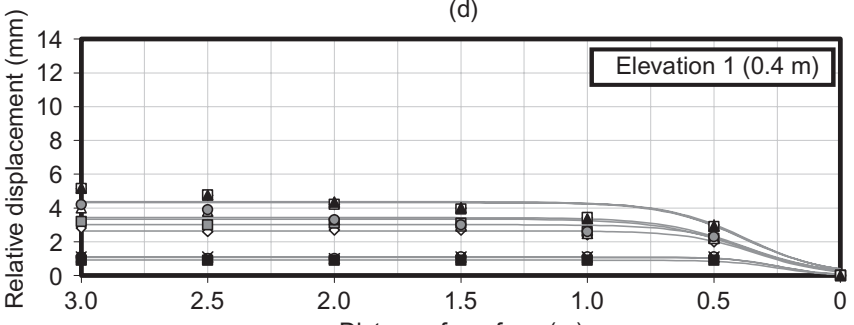

- Fourth layer

$x$ Sixth layer

- Ninth layer

$\diamond$ End of construction

$\square 7$ days

$\triangle 15$ days

027 days

+57 days

$\square 84$ days

$\Delta 203$ days

(e)

Figure 19. Reinforcements displacements measured by extensometers: (a) elevation 1; (b) elevation 2; (c) elevation 3; (d) elevation 4; (e) elevation 5

of the total registered displacements), reaching $21 \mathrm{~mm}$ in the center of the reinforced zone (extensometer 2), and approximately $15 \mathrm{~mm}$ towards both edges of the reinforced zone (extensometers 1 and 3). The displacements did not increase significantly with time $(2 \mathrm{~mm}$ after 200 days).

\section{CONCLUSIONS}

This study presents a description of the characteristics and construction of a prototype geotextile-reinforced wall. This wall is the baseline structure for a series of eight reinforced prototype walls constructed to assess the deformability of geotextile-reinforced walls. An overview of the material characterization programs, deformability data, predicted strains, and design implications of the monitored results are also presented. The field monitoring program involved measurement of vertical and horizontal displacements within the reinforced soil mass, as well as face displacements. The measurements were conducted both during and after construction of the wall. The main conclusions from the evaluation of the performance of the geotextile-reinforced wall are as follows.

- Most lateral displacements occurred towards the wall face, reaching $13 \mathrm{~mm}$ at mid-height of the wall, as measured by horizontal extensometers. The lateral displacements were observed to increase with time, 


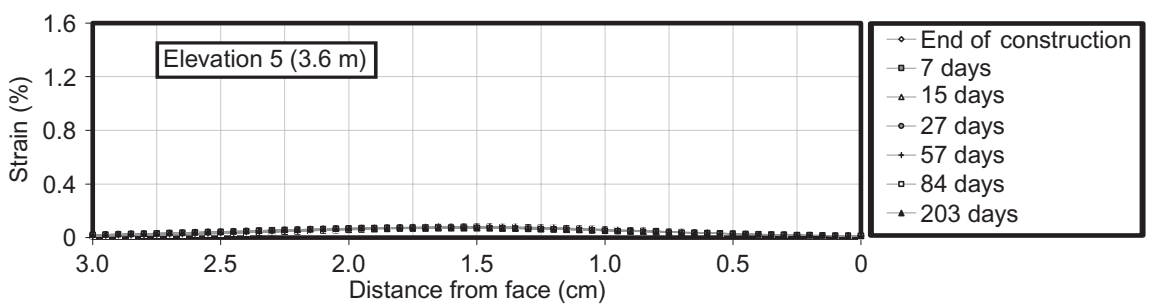

(a)

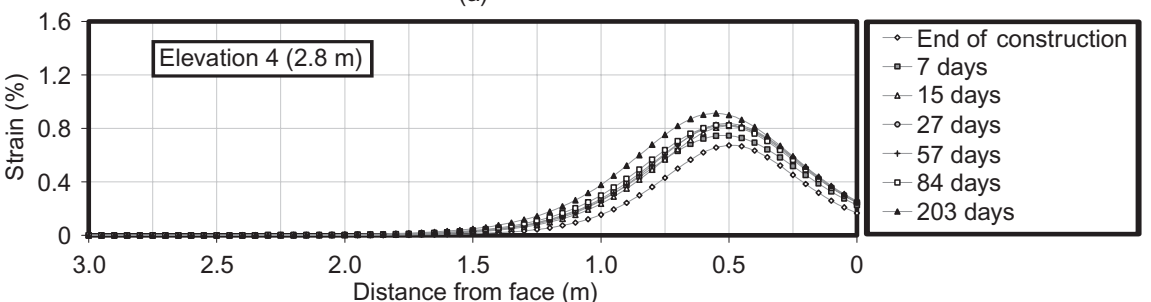

(b)

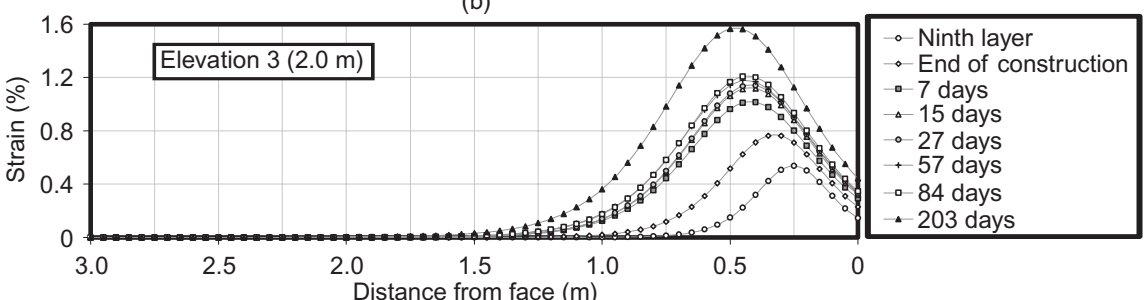

(c)

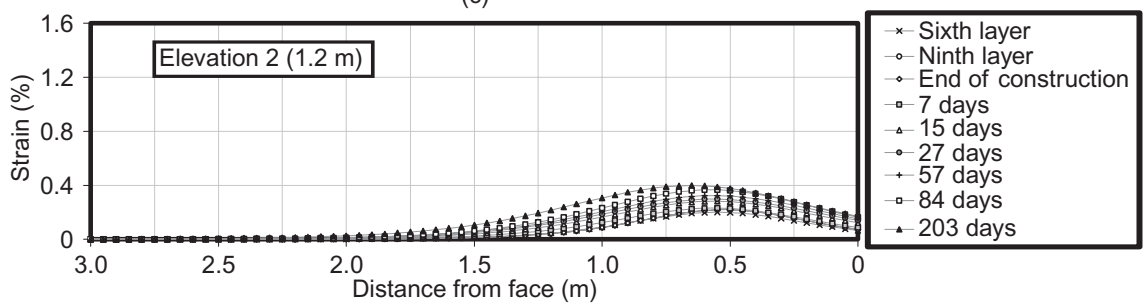

(d)

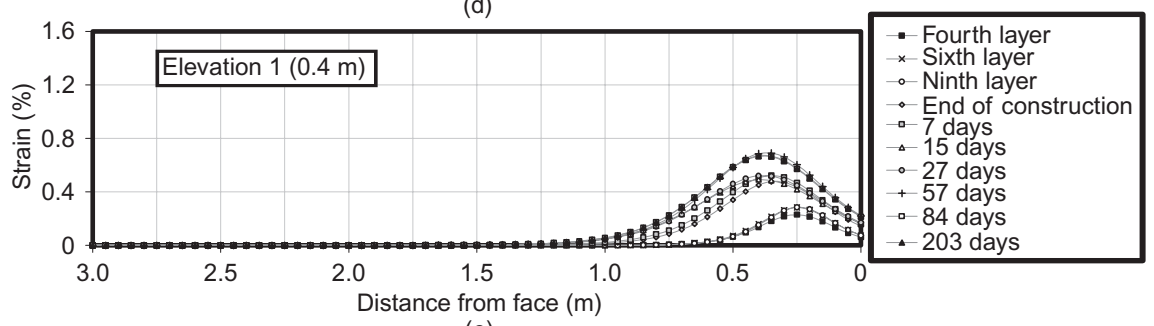

(e)

Figure 20. Reinforcement strains: (a) elevation 1; (b) elevation 2; (c) elevation 3; (d) elevation 4; (e) elevation 5

particularly in association with precipitation events during the summer season in Brazil.

- The horizontal displacements at the face, surveyed from a fixed external reference, were larger than those measured by extensometers. The external face displacements, taken in the middle of each layer, incorporated localized displacements due to soil particle rearrangement at the flexible facing (sagging). The location of higher displacements observed after construction (mid-height of the wall) is consistent with that obtained using extensometers.

- $\quad$ The reinforcement strains were comparatively small. The largest strains $(0.8 \%)$ occurred at mid-height of the prototype wall. Additional strains took place after construction, reaching a maximum value of $1.3 \%$ after 203 days.

- $\quad$ The use of sigmoid curves to fit displacement results was found to be very useful for defining the value and location of the peak strain in each reinforcement layer.

- The location of maximum reinforcement strains within each layer is consistent with the development of a potential failure surface starting at the toe of the wall and propagating into the soil mass.

- The maximum reinforcement tension predicted using the K-stiffness method compared relatively well with reinforcement tension values obtained using the measured displacement values in prototype wall 1 .

- The largest settlements at the foundation level occurred in the middle of the reinforced zone.

- Overall, the geotextile-reinforced wall showed a performance that is consistent with current design methods and, in spite of the low reduction factors considered in the design of the prototype wall, resulted in comparatively small displacements during and after construction. 


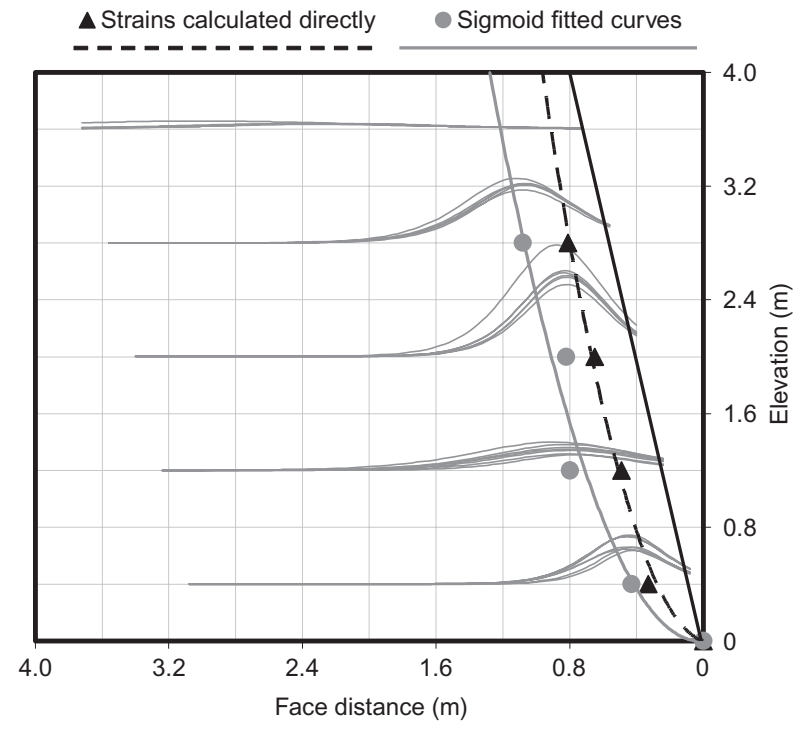

Figure 21. Potential slip surface, defined as locus of maximum strains

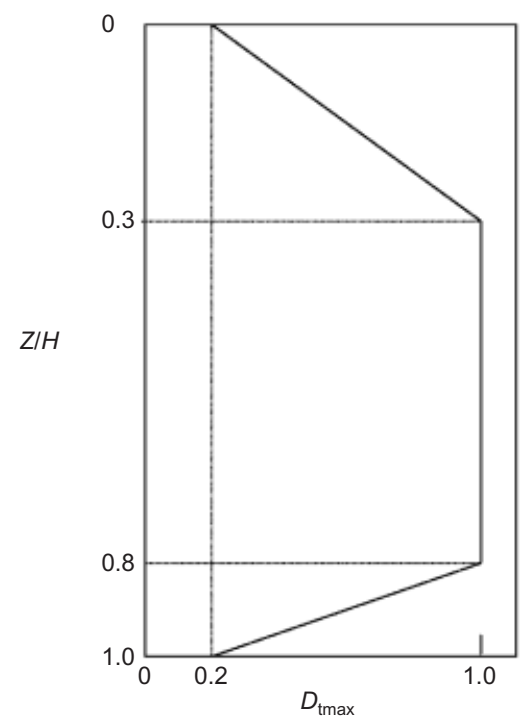

Figure 22. Distribution of $D_{\text {tmax }}$ with normalized depth below wall top (Allen and Bathurst 2003, Bathurst et al. 2005)

\section{ACKNOWLEDGMENTS}

This research received financial support from Ober S.A., FAPESP and CAPES in Brazil. Support received by the third author from the National Science Foundation in the USA under Grant No. CMS-0070248 is also acknowledged.

\section{NOTATIONS}

Basic SI units are given in parentheses.
$a, b, c$ sigmoid curve-fitting constants (dimensionless)
a local reinforcement stiffness coefficient (dimensionless)

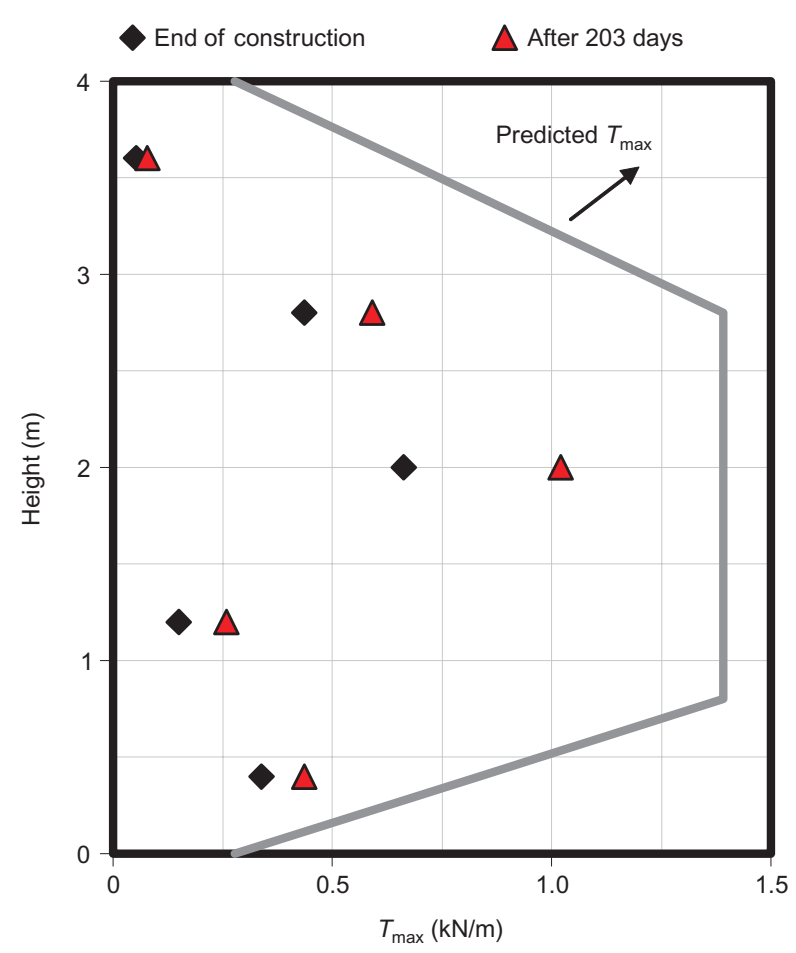

Figure 23. Tensile loads in reinforcement layers

COV coefficient of variation (standard deviation/ mean) (dimensionless)

$d$ facing batter coefficient (dimensionless)

$D_{\text {tmax }}$ reinforcement load distribution factor (= $T_{\max } / T_{\operatorname{mxmx}}$ ) (dimensionless)

$d$ displacement from sigmoid curve-fitting (m)

$e_{\max }, e_{\min }$ maximum and minimum void ratio (dimensionless)

$H$ height of wall $(\mathrm{m})$

$i$ counter $(1,2,3, \ldots, n)$

$J, J_{i}$ tensile stiffness of reinforcement $(\mathrm{N} / \mathrm{m})$

$J_{\text {ave }}$ average tensile stiffness of reinforcement layers in wall $(\mathrm{N} / \mathrm{m})$

$K$ coefficient of lateral earth pressure (dimensionless)

$K_{\text {abh }}$ coefficient of horizontal active earth pressure accounting for wall batter (dimensionless)

$K_{\mathrm{abv}}$ coefficient of horizontal active earth pressure for $\omega=0$ (dimensionless)

$N$ Standard Penetration Test blow count (dimensionless)

$n$ total number of reinforcement layers in wall section (dimensionless)

$p_{\mathrm{a}} \quad 101 \mathrm{kPa}$ (atmospheric pressure)

$q$ surcharge pressure $(\mathrm{Pa})$

$S$ equivalent soil height of uniform surcharge pressure $(=q / \gamma)(\mathrm{m})$

$S_{\text {global }}$ global reinforcement stiffness value $\left(\mathrm{N} / \mathrm{m}^{2}\right)$

$S_{\text {local }}$ local reinforcement stiffness value $\left(\mathrm{N} / \mathrm{m}^{2}\right)$

$S_{\mathrm{V}}$ tributary area for reinforcement layer (assumed equivalent to vertical spacing of reinforcement when analyses are carried out per unit length of wall) (m) 


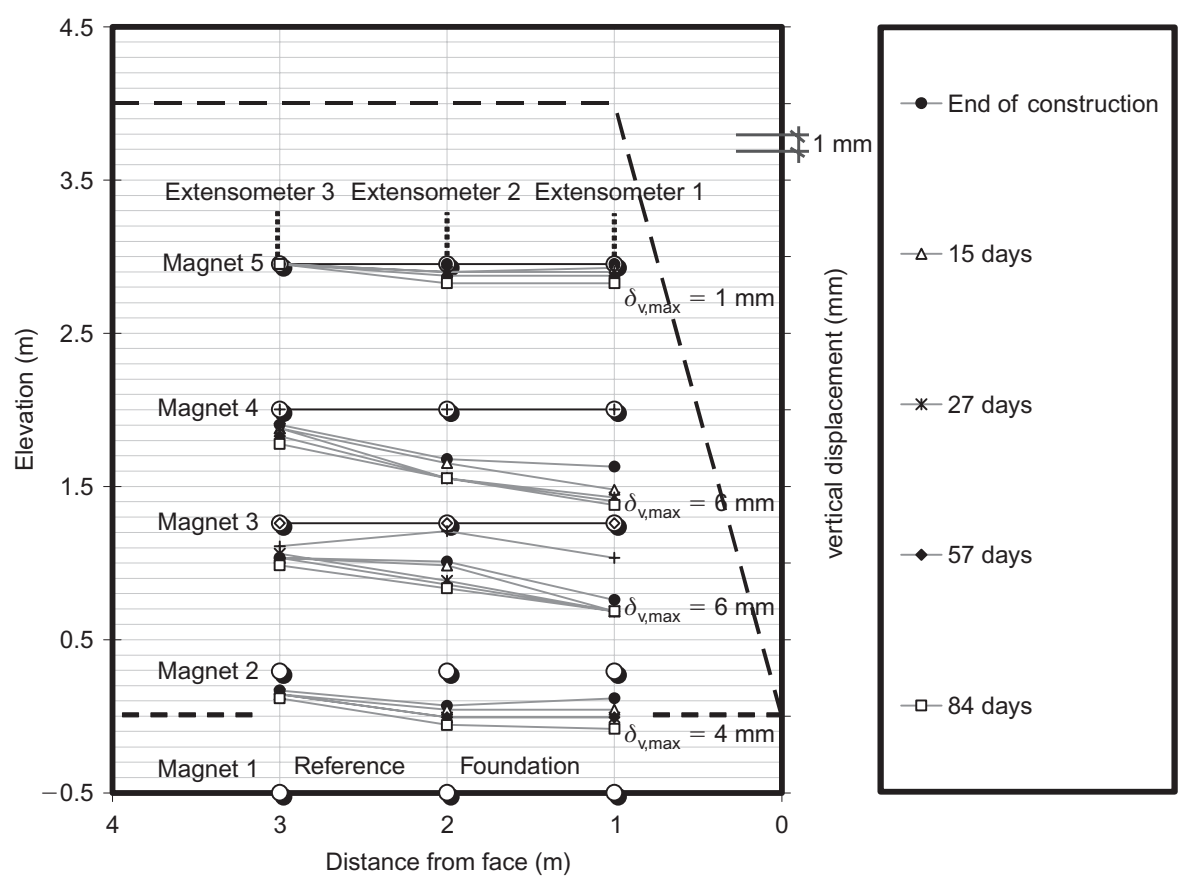

Figure 24. Vertical displacements in reinforced backfill, as measured by magnetic extensometers

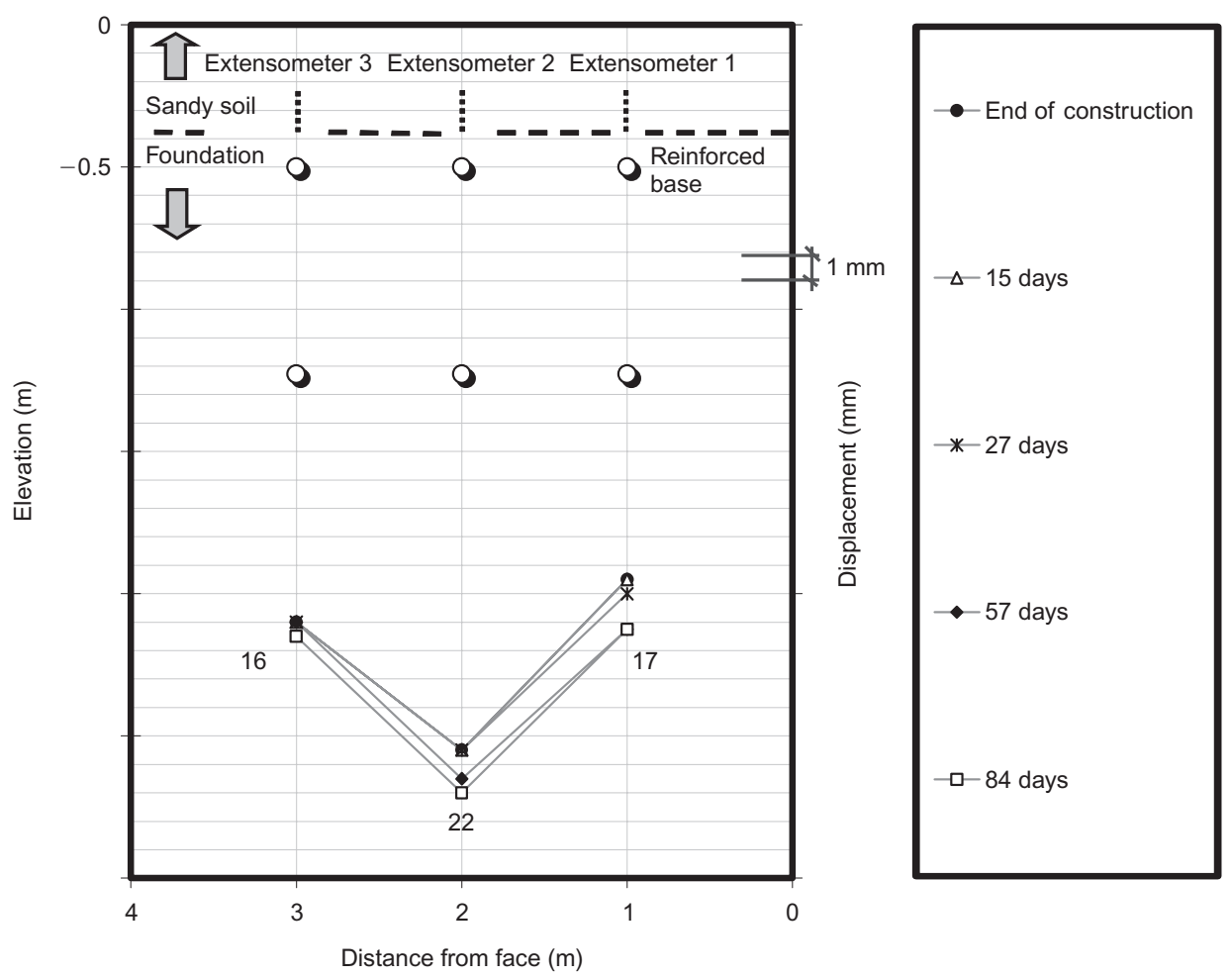

Figure 25. Vertical settlements at foundation

$T_{\max }$ maximum reinforcement load in a layer $(\mathrm{N} / \mathrm{m})$

$T_{\mathrm{mxmx}}$ maximum reinforcement load from all layers in wall $(\mathrm{N} / \mathrm{m})$

$x$ location along reinforcement length $(\mathrm{m})$

$x_{\max }$ maximum displacement location (m)

$\gamma$ unit weight of soil $\left(\mathrm{N} / \mathrm{m}^{3}\right)$

$\delta$ interface friction angle (degrees) $\varepsilon_{\max }$ maximum reinforcement strain in layer (dimensionless)

$\Phi_{\mathrm{fb}} \quad$ facing batter factor (dimensionless)

$\Phi_{\mathrm{fs}}$ facing stiffness factor (dimensionless)

$\Phi_{\mathrm{g}}$ global stiffness factor (dimensionless)

$\Phi_{\text {local local stiffness factor (dimensionless) }}$

$\phi \quad$ friction angle of soil (degrees) 


\section{REFERENCES}

Allen, T. M \& Bathurst, R. J. (2003). Prediction of Reinforcement Loads in Reinforced Soil Walls. Report WA-RD 522.2, Washington State Department of Transportation, Olympia, Washington.

Allen, T. M, Bathurst, R. J. \& Berg, R. R. (2002). Global level of safety and performance of geosynthetic walls: an historical perspective. Geosynthetics International, 9, Nos. 5-6, 395-450.

Arthur, J. R. F. \& Roscoe, K. H. (1965). An examination of the edge effects in plane-strain model earth pressure tests. Proceedings of the 6th International Conference on Soil Mechanics and Foundation Engineering, Montreal, Canada, Vol. II, Div. 3-6, pp. 363-367.

ASTM D 2487. Standard Practice for Classification of Soils for Engineering Purposes (Unified Soil Classification System). ASTM International, West Conshohocken, PA.

ASTM D 4253. Standard Test Methods for Maximum Index Density and Unit Weight of Soils Using a Vibratory Plate (Unified Soil Classification System). ASTM International, West Conshohocken, PA.

ASTM D 4254. Standard Test Methods for Minimum Index Density and Unit Weight of Soils and Calculation of Relative Density (Unified Soil Classification System). ASTM International, West Conshohocken, PA.

ASTM D 4595. Standard Test Method for Tensile Properties of Geotextiles by the Wide-Width Strip Method (Unified Soil Classification System). ASTM International, West Conshohocken, PA.

Baras, L. C. S., Bueno, B. S. \& Costa, C. M. L. (2002). On the evaluation of stepped isothermal method for characterizing creep properties of geotextiles. Proceedings of the 7th International Conference on Geosynthetics, Nice, France, Vol. 4, pp. 1515-1518.

Bathurst, R. J., Benjamin, D. J. \& Jarret, P. M. (1989). An instrumented geogrid reinforced soil wall. Proceedings of the 12th International Conference on Soil Mechanics and Foundation Engineering, Rio de Janeiro, Vol. 2, pp. 1223-1226.

Bathurst, R. J, Allen, T. M. \& Walters, D. L. (2005). Reinforcement loads in geosynthetic walls and the case for a new working stress design method. Geotextiles and Geomembranes, 23, No. 4, 287-322.

Bathurst, R. J., Vlachopoulos, N., Walters, D. L., Burgess, P. G. \& Allen, T. M. (2006). The influence of facing rigidity on the performance of two geosynthetic reinforced soil retaining walls. Canadian Geotechnical Journal, 43, No. 12, 1225-1237.

Carvalho, P. A. S., Wolle, C. M. \& Pedrosa, J. A. B. A. (1986). Aterro reforçado com geotêxteis - uma opção alternativa para a engenharia geotécnica. Proceedings of the 8th Brazilian Conference on Soil Mechanics and Foundation Engineering, Porto Alegre, Brazil, Vol. 4, pp. 169-178.

Christopher, B. R. (1993). Deformation Response and Wall Stiffness in Relation to Reinforced Soil Design. PhD thesis, Purdue University.

Cruz, P. T. (1996). 100 Brazilian Dams. Oficina de Textos, São Paulo (in Portuguese).

Ehrlich, M., Vidal, D. \& Carvalho, P. A. (1997). Performance of two geotextile reinforced soil slopes. Proceedings of the International Symposium on Recent Developments in Soil and Pavement Mechanics, Rio de Janeiro. Balkema, Rotterdam, pp. 415-420.
Elias, V., Christopher, B. R. \& Berg, R. R. (2001). Mechanically Stabilized Earth Walls and Reinforced Soil Slopes: Design and Construction Guidelines, Report No. FHWA-NHI-00-043. Federal Highway Administration, Washington, DC, USA, 394 pp.

Farrag, K. \& Morvant, M. (2004). Evaluation of Interaction Properties of Geosynthetics in Cohesive Soils: LTRC Reinforced-Soil Test Wall, LTRC Project No. 92-4GT. State Project No. 736-99-0658. Louisiana Department of Transportation and Development and Louisiana Transportation Research Center, $156 \mathrm{pp}$.

Gomes, R. S. (1992). Interação solo-reforço e mecanismos de ruptura em solos reforçados com geotêxteis. $\mathrm{PhD}$ thesis, Escola de Engenharia de São Carlos,USP, Universidade de São Paulo, São Carlos, Brazil, $271 \mathrm{pp}$.

ISO (1999). ISO 13341: Geotextile and Geotextile Related Products: Determination of Tensile Creep and Creep Rupture Behavior. International Organization for Standardization, Geneva, Switzerland.

Kamiji, T. S. M. M. (2006). Fluência de geotêxteis não tecidos através de ensaios confinados. MSc dissertation, Escola de Engenharia de São Carlos, Universidade de São Paulo, São Carlos, Brazil, 134 pp.

Mitchell, J. K. \& Villet, W. C. B. (1987). Reinforcement of Earth Slopes and Embankments. National Cooperative Highway Research Program Report, No. 290, Transportation Research Board, National Research Council, Washington, DC, USA.

Nogami, J. S. \& Villibor, D. F. (1981). Uma nova classificação de solos para finalidades rodoviárias. Simpósio Brasileiro de Solos Tropicais em Engenharia, Rio de Janeiro, Vol. 1, pp. 30-40.

Pedroso, E. O., Bueno, B. S., Benjamim, C. V. S. \& Zornberg, J. G. (2006). Field monitoring and numerical prediction of the response of a non-woven geotextile-reinforced wall. Proceedings of the 8th International Conference on Geosynthetics, Yokohama, Japan, Vol. 3, pp. 1129-1132.

Ribeiro, T. S. M. T., Vicenzo, M. C. Jr \& Pires, J. V. (1999). Comportamento do aterro de solo reforçado da encosta do Belvedere. Proceedings of the 9th Congresso Brasileiro de Geologia de Engenharia, São Pedro, Brazil, CD-ROM.

Vidal, H. (1966). La Terre Armée: réalisations récentes. Annales de l'Institut Technique du Batiment et des Travaux Publics, 21, Nos. 259 (July)-260 (August).

Wu, J. T. H. (1992). Predicting performance of the Denver walls: general report. In Proceedings of the International Symposium on Geosynthetic-Reinforced Soil Retaining Walls, Denver, CO, USA. Balkema, Rotterdam, The Netherlands, pp. 3-20.

Zornberg, J. G. \& Arriaga, F. (2003). Strain distribution within geosynthetic-reinforced slopes. Journal of Geotechnical and Geoenvironmental Engineering, ASCE, 129, No. 1, 32-45.

Zornberg, J. G. \& Mitchell, J. K. (1994). Reinforced soil structures with poorly draining backfills. Part I: Reinforcement interactions and functions. Geosynthetics International, 1, No. 2, 103-148.

Zornberg, J. G., Sitar, N. \& Mitchell, J. K. (1997). Failure of steep reinforced soil slopes. Proceedings of the Geosynthetics ' 97 Conference, Long Beach, CA, Vol. 1, pp. 55-72.

Zornberg, J. G., Sitar, N. \& Mitchell, J. K. (1998). Performance of geosynthetic reinforced slopes at failure. Journal of Geotechnical and Geoenvironmental Engineering, ASCE, 124, No. 8, 670-683.

The Editors welcome discussion on all papers published in Geosynthetics International. Please email your contribution to discussion@geosynthetics-international.com by 15 October 2007. 